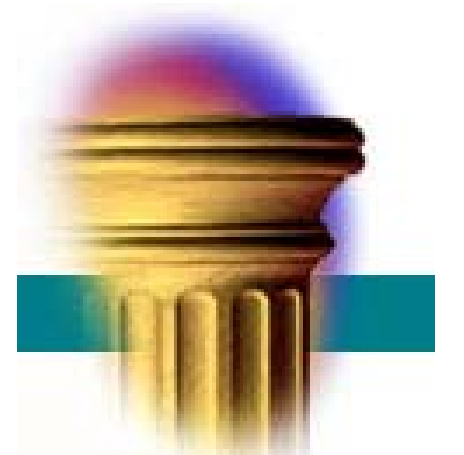

8

苂

Do Safeguard Tariffs and Antidumping Duties Open or Close Technology Gaps?

\author{
Meredith A. Crowley
}

4

$\frac{v}{\sigma}$

m

0
0
0
0
0
0
0
0
0
0
0

Revised February 10, 2003

WP 2002-13 


\title{
Do Safeguard Tariffs and Antidumping Duties Open or Close Technology Gaps?
}

\author{
Meredith A. Crowley* \\ Economic Research \\ Federal Reserve Bank of Chicago \\ mcrowley@frbchi.org
}

First version: July 30, 2002

This version:

February 10, 2003

\begin{abstract}
This paper examines how the country-breadth of tariff protection can affect the technology adoption decisions of both domestic import-competing and foreign exporting firms. The analysis is novel in that shows how firm-level technology adoption changes under tariffs of different country-breadth. I show that a country-specific tariff like an antidumping duty induces both domestic import-competing firms and foreign exporting firms to adopt a new technology earlier than they would under free trade. In contrast, a broadly-applied tariff like a safeguard can accelerate technology adoption by a domestic import-competing firm, but will slow-down technology adoption by foreign exporting firms. Because safeguard tariffs can delay the foreign firm's adoption of new technology, the worldwide welfare costs associated with using them may be larger than is generally believed.
\end{abstract}

${ }^{*}$ I thank Bob Staiger, Scott Taylor and Yuichi Kitamura for detailed comments and encouragement. I also thank Bob Baldwin, Eric French, Tom Prusa and seminar participants at the University of Wisconsin-Madison, the Federal Reserve Bank of Chicago, the Federal Reserve Board of Governors, Purdue University, SUNY - Stony Brook, the Bureau of Labor Statistics, the Federal Reserve System Committee on International Economic Analysis Spring 2001 Meetings, the Midwest International Economics Group Fall 2001 Meetings and the NBER's 2002 Universities' Research Conference on Firm-level Responses to Trade Polices. The opinions expressed in this paper are those of the author and do not necessarily reflect those of the Federal Reserve Bank of Chicago or the Federal Reserve System. 


\section{Introduction}

Over the last twenty years, the world has witnessed a dramatic increase in the use of industryspecific import restraints like antidumping duties, safeguard measures, and voluntary restraint agreements. Although protection-seeking industries often claim that they are the victims of "unfair" trade, in many cases, it is clear that a domestic industry's falling market share is due to its technological inferiority relative to its foreign competitors. This paper explores how the countrybreadth of tariff protection affects the technology adoption decisions of import-competing and exporting firms.

For example, the US saw steel imports increase from $7.3 \%$ of the US market in 1964 to $16.7 \%$ in 1968 after European and Japanese steel producers adopted a major technological innovation, the basic oxygen furnace. ${ }^{1}$ From 1969 to 1974, the US government responded to this import surge with country-specific import restraints. In this instance, the US negotiated voluntary restraint agreements with the EC and Japan. These import restrictions had two notable effects. First, steel imports from countries not covered by the agreement rose. Second, the US industry failed to catchup technologically. In 1974 , when $80.9 \%$ of Japanese production and $68.8 \%$ of German production utilized the basic oxygen furnace, only $56.0 \%$ of US steel production utilized the new technology. ${ }^{2}$

In the 1980s and 1990s, technology in steel production continued to improve with the development of continuous casting, another cost-reducing production technology. The US government again responded to import surges from technological leaders with country-specific antidumping duties and voluntary restraint agreements. ${ }^{3}$ The results of protection were the same as before. Imports from countries not covered by the import restraints rose. ${ }^{4}$ Moreover, the US remained technologically behind. In 1982, only $26.9 \%$ of US production utilized continuous casting compared to $78.7 \%$ of Japanese production and $61.9 \%$ of German production. By 1992, the absolute technology position of the US was much better; $79.3 \%$ of US production utilized continuous casting. However, the US was still behind its traditional competitors - 92.0\% of German production and

\footnotetext{
${ }^{1}$ See Moore, 1996.

${ }^{2}$ OECD, 1974.

${ }^{3}$ An exception to the general practice of country-specific protection was the use of the Trigger Price Mechanism from 1977 to 1982 which imposed a price floor on imports from all countries.

${ }^{4}$ See Prusa, 2001 and Moore, 1996.
} 
95.4\% of Japanese production now used continuous casting - and had been leapfrogged by Turkey and Korea which used continuous casting for $82.2 \%$ and $96.8 \%$ of production, respectively.

Despite the dismal history of steel, the American experience with trade protection and technology adoption has not been universally bad. In 1983, in the face of rising imports of Japanese motorcycles, the US government temporarily raised its tariff on motorcycles. The goal was to help the American producer, Harley-Davidson, implement its plan to introduce "innovative new management and manufacturing techniques, many of which were learned from [Harley-Davidson's] Japanese competitors." 5 This experiment in using the multi-country "safeguard tariff" to assist a firm in adopting the technology of its foreign rivals turned out to be a success - by 1986 HarleyDavidson had closed the technology gap. It had "revitalized its manufacturing and streamlined its operations" ${ }^{\prime}$, had reclaimed the top spot in the US superheavyweight motorcycle market, and had begun a resurgence in which the firm has steadily increased both its profitability and market share up to the present day. Interestingly, unlike the US experience with steel protection, the comprehensive safeguard tariff didn't lead to trade diversion. In fact, under the safeguard tariff, imports of motorcycles from Japan grew $17.6 \%$ between 1984 and 1985 while growth of imports from Germany was only $7 \%$ and imports from Italy fell $11.0 \%{ }^{7}$

Why were the outcomes of trade protection so different? This paper attempts to explain how differences in the breadth of trade protection could have affected technology adoption by these two industries. Specifically, it analyzes technology adoption decisions under country-specific tariffs, like antidumping duties and voluntary restraint agreements, and broadly-applied, multicountry protection, like safeguard tariffs. ${ }^{8}$ Moreover, it examines how these tariffs affect the technologyadoption decisions of both domestic import-competing and the foreign exporting firms they compete against.

\footnotetext{
${ }^{5}$ Harley-Davidson Motor Company, 2000, p. 2.

${ }^{6}$ Ibid.

${ }^{7}$ Author's calculation for motorcycles with engines 700 cc's or larger from "US Imports for Consumption and General Imports, TSUSA Commodity by Country of Origin, FT246," Bureau of the Census, Washington, DC 19721988. Because the safeguard was imposed in mid-1983, 1984 is the first year for which data on imports under the safeguard are available.

${ }^{8}$ In this paper, I use the term antidumping duty to refer to country-specific trade protection and use the term safeguard tariff to refer to multicountry protection. In practice, there are exceptions to this general rule. After 1984, antidumping protection could be comprehensively applied to all import sources if multiple petitions were filed simultaneously. Also, prior to 1994, safeguard protection could be applied to a single country.
} 
This is the first paper to analyze the relationship between the breadth of trade protection and technology adoption. In exploring how tariffs affect technology adoption, I draw from the technology adoption literature (Reinganum, 1981a, 1981b; Fudenberg and Tirole, 1985) in which ex ante identical firms compete in the dates at which they adopt an existing, widely available technology whose cost of adoption is decreasing with time. My research complements Matsuyama (1990) and Miyagiwa and Ohno $(1995,1999)$ who study how the duration of trade protection can affect the adoption of an existing technology. They show that when the duration of protection is endogenous to the domestic firm's decision of when to adopt the new technology, the new technology is never adopted. I abstract from this problem by examining permanent protection. Miyagiwa and Ohno (1995) show that permanent protection is equivalent to temporary protection with a minimum duration and a termination date that is exogenous to the domestic firm's technology adoption decision. Because safeguards face WTO-enforced time limits and the duration of antidumping protection depends on foreign firms' behavior and, since 1994, is limited to 5 years in most cases, analyzing permanent protection is a reasonable simplification. Lastly, by examining the welfare consequences of technology adoption under country-specific and broadly-applied tariffs, this paper contributes to a large literature (Bagwell and Staiger, 1999; Ethier, 1998) which analyzes the welfare properties of country-specific tariffs in the context of regional and multilateral trade agreements.

This paper uses a segmented markets model in which three firms in three different countries one importing country and two exporting countries - compete on quantity. At some time, the firm in one foreign exporting country discovers and adopts a new technology. The import-competing firm and the firm in the second foreign country then decide when to adopt the new technology. When the cost of technology adoption is decreasing with time but is a fixed cost at any moment in time, a firm that faces a large worldwide market has an incentive to adopt the new technology relatively early. I show that when the import-competing firm and the firm in the second foreign country are sufficiently similar in terms of the size of the worldwide market they face, it is indeterminate which country will adopt the new technology first in the pure strategy Nash equilibrium under free trade. If one firm faces a worldwide market that is sufficiently larger than its competitor's, it will adopt the new technology first.

Protection under a multicountry safeguard tariff and a country-specific antidumping duty 
changes the equilibrium in the technology adoption game. Country-specific antidumping duties advance the date of technology adoption for both the import-competing firm and the second foreign firm. They do this by reducing the market share of the technologically superior foreign firm and increasing the market shares of both the domestic firm and the second foreign firm. By increasing both firms' market shares, the antidumping duty creates an incentive for both firms to adopt the new technology earlier than they would under free trade. Because the antidumping duty doesn't change the relative market shares of these two firms, it doesn't alter the equilibrium order of technology adoption. In contrast, a multicountry safeguard tariff advances the date of technology adoption by the import-competing firm and delays the date of technology adoption by the second foreign firm. This happens because the safeguard tariff increases the market share of the domestic firm and reduces the market shares of both foreign firms. Moreover, the safeguard tariff changes the relative market shares of the domestic firm and the foreign firm that does not have the new technology. By changing the relative market shares of these two firms, the safeguard tariff can alter the equilibrium order of adoption. When the safeguard tariff increases the domestic firm's market share above a critical threshold, the domestic firm "leap-frogs" the second foreign firm in the technology adoption race.

In summary, tariffs of different country-breadth have different effects on technology adoption. The safeguard tariff closes one technology gap - that between the domestic import-competing firm and foreign firm that precedes it in technology adoption - but, it also opens a second technology gap by delaying the second foreign firm's technology adoption. Although a safeguard tariff can improve the welfare of an importing country by accelerating its technological progress, it can also cause worldwide welfare losses by delaying technology adoption among foreign exporting firms. In contrast, if an importing country imposes an antidumping duty against a technologically superior foreign firm, this closes the technology gap between the initial foreign innovator and the firms in all other countries that are technologically behind it. In terms of worldwide welfare, earlier technology adoption by firms in all countries yields dynamic gains but the antidumping duty itself imposes static costs.

Another motivation behind this paper is to question a conventional wisdom that has arisen among some economists and trade policy makers. It is widely understood that antidumping duties 
impose a high welfare cost on consumers (see Gallaway, Blonigen and Flynn, 2000; Staiger and Wolak, 1994 and Prusa, 2001) and are a tax that addresses no fundamental market failure. ${ }^{9}$ Gruenspecht (1988), Anderson (1992), and Clarida (1993) suggest that dumping is a profit-maximizing strategy for a foreign firm and imply that antidumping duties are welfare-reducing. However, safeguard tariffs have been less costly to consumers (Baldwin, 1985; Finger, Hall and Nelson, 1982; and Hansen and Prusa, 1995), less distortionary to worldwide trade flows, and may be beneficial to importing countries because they allow governments some flexibility in setting policy (Bagwell and Staiger, 1990; Ethier, 1998; Fischer and Prusa, 1999). Trade lawyers and policymakers like Bhala (1996) and Jackson (1989) have developed this viewpoint to suggest that reform of trade policy include elimination of antidumping policy and expansion of the safeguard policy. ${ }^{10}$

However, the arguments that safeguards are somehow better than antidumping duties tend to rest on static measures of the welfare consequences of trade protection. The difference in the dynamic welfare costs of these policies has not been thoroughly examined. This paper suggests that by delaying technology adoption in foreign countries, the dynamic costs of using safeguard tariffs may be larger than those associated with antidumping duties.

Section 2 outlines the model. Section 3 presents the technology adoption game and the equilibrium technology adoption dates under different trade policies. Section 4 analyzes the importing country's welfare under different trade policies. Section 5 concludes.

\section{The Model}

To study how the breadth of tariff protection affects the decisions of firms, I construct a partial equilibrium model of a world with three countries, two foreign countries (denoted A and B) and one domestic country (called home and indexed H). I restrict my attention to imperfectly competitive industries because antidumping duties and safeguard tariffs are often used in industries with

\footnotetext{
${ }^{9}$ An exception to this general rule is Hartigan (1996) which examines predatory dumping arising from a capital market imperfection.

${ }^{10}$ Bhala (1996) has argued, "antidumping law is unnecessary. Injury to an industry in an importing country caused by imports can be addressed by safeguard actions... Applying [safeguard actions] in the context of dumping is legitimate because dumping is not necessarily unfair." Jackson (1989) supports this by claiming that "...unfair trade [i.e. dumping] also causes burdens of adjustment and so arguably qualifies for safeguards policies."
} 
relatively small numbers of producers. ${ }^{11}$ By assuming there is one firm in each country, markets are segmented, and the goods produced in each country are perfect substitutes, I can tie-down the country-specific volume of trade and simplify analysis of the strategic behavior of firms. To further simplify the analysis, I assume the foreign markets are closed to each other and to the home firm. The firms in the foreign countries sell their output in their own market and in the home country's market, but the home firm sells its output in only its own market. See figure 1 for a diagram of trade flows.

Initially, the three firms have identical technologies. I assume the firm in country A discovers and adopts a new, low-cost technology. This new technology is widely available to firms everywhere and its cost of adoption is falling over time. For example, cost-reducing process innovations like the basic oxygen furnace, continuous casting, industrial robots, computers and machine vision would satisfy this assumption. The advent of this new technology induces a technology adoption race between the import-competing firm in the home country and the firm in country B. I characterize the Nash equilibrium of this game under free trade, safeguard tariffs, and antidumping duties. ${ }^{12}$

\subsection{Instantaneous Profits}

The three firms, called A, B, and home, play an infinitely-repeated quantity-setting game. At every moment in time, firms choose their quantities simultaneously to maximize profits given their current technology level. I assume that firms follow Markov strategies in order to restrict my attention to the non-cooperative equilibrium in the repeated quantity-setting game.

The technology level of a firm at any point in time is simply its marginal cost of production at that time, $\gamma^{i}$ where $i=a, b, h$. The technology level of any firm can take on two values, $\gamma^{i} \in\{\underline{\gamma}, \bar{\gamma}\}$

\footnotetext{
${ }^{11}$ Under US trade law, an industry must pay legal fees in order to request trade protection. The free-rider problem could explain why protection is most often sought by industries with relatively few producers. Alternatively, in industries with many producers, management quality may vary widely across domestic firms and the government may be less likely to find injury is caused by imports.

${ }^{12}$ The Nash equilibrium rules out by assumption the possibility of pre-emption in technology adoption. Fudenberg and Tirole (1985) have shown that, in a continuous time technology adoption game with two identical firms, allowing for pre-emption causes the equilibrium dates of technology adoption to occur earlier and rents to be equalized between the two firms. When rents are equalized, firms are indifferent between being the leader or follower in technology adoption. In this paper, I analyze what Fudenberg and Tirole call a "precommitment equilibrium." Oster (1982) finds that plant-specific characteristics are important determinants of the dates at which US steel firms adopted the basic oxygen furnace and continuous casting. Thus, plant-specific characteristics may act as pre-commitment devices.
} 
where $\underline{\gamma}$ is the new or low-cost technology and $\bar{\gamma}$ is the old or high cost technology $(\underline{\gamma}<\bar{\gamma})$. Initially, all three firms have the old, high-cost technology.

Inverse demand in the home country is given by $p\left(q, M^{a}, M^{b}\right)$ where $q$ is the home firm's output and $M^{i}$ is imports from firm $i$ into the home country. In order to derive a precise analytic relationship among any tariff, each firm's equilibrium quantity, and the order of technology adoption, I assume inverse demand is linear and that the domestically-produced good and the foreign-produced goods are perfect substitutes, $p\left(q, M^{a}, M^{b}\right)=a-\left(q+M^{a}+M^{b}\right)$. Similarly, inverse demand in each foreign country $i$ is linear, $p^{i}\left(q^{i}\right)=a^{i}-q^{i}$. Thus, the instantaneous equilibrium profits of firms are given by the following.

$$
\begin{aligned}
\pi^{h} & =\frac{1}{16}\left(a-3 \gamma^{h}+\gamma^{i}+\gamma^{j}+\tau^{i}+\tau^{j}\right)^{2} \\
\pi^{i} & =\frac{1}{4}\left(a^{i}-\gamma^{i}\right)^{2}+\frac{1}{16}\left(a-3\left(\gamma^{i}+\tau^{i}\right)+\gamma^{h}+\gamma^{j}+\tau^{j}\right)^{2}
\end{aligned}
$$

for $i=a, b, i \neq j$ where $\tau^{i}$ is the tariff imposed by the home country against imports from country $i$.

The profits of each firm are increasing in the size of the market(s) it serves. Because the cost of adoption at any point in time is a fixed cost, the firm the serves the larger market(s) and can spread the cost of adoption over more units will have an incentive to adopt earlier.

\subsection{A technological improvement in a foreign country}

At some time denoted $t=0$, firm A experiences a positive technology shock; its marginal cost of production falls to $\underline{\gamma}$. This causes firm A to increase its exports to the home country. At any time $t>0$, the new technology of firm A can be acquired by the home firm and the firm in country $\mathrm{B}$ at a cost $C(t)$ that decreases with time $C^{\prime}(t)<0$ and $C^{\prime \prime}(t) \geq 0$. Thus, the advent of the new technology kicks-off a technology adoption race between the home country's firm and the firm in country B in which each firm must choose its date of technology adoption, $t^{h}$ and $t^{b}$, respectively.

To simplify notation, let $\pi^{i}\left(\bar{\gamma}^{h}, \bar{\gamma}^{b}\right)$ denote the instantaneous profits of firm $i=h, b$ when both the home firm and firm B have the old technology, $\pi^{i}\left(\bar{\gamma}^{h}, \underline{\gamma}^{b}\right)$ denote firm $i=h, b$ 's profits when 
the home firm has the old technology and firm B has the new technology, $\pi^{i}\left(\underline{\gamma}^{h}, \bar{\gamma}^{b}\right)$ denote firm $i=h, b$ 's profits when the home firm has the new technology and firm B has the old technology, and $\pi^{i}\left(\underline{\gamma}^{h}, \underline{\gamma}^{b}\right)$ denote firm $i=h, b$ 's profits when both firms have the new technology. Firm A's new technology level is given by $\gamma^{a}=\underline{\gamma}$ after $t=0$ and is suppressed for clarity. Lastly, the tariffs imposed against country A and country B are permanent and are suppressed for clarity of notation. $^{13}$

Linear demand and constant marginal cost imply the following relationships about instantaneous profits under different technology levels for any set of non-prohibitive tariffs $\left(\tau^{a}, \tau^{b}\right)$ that are constant over time. First, the profits of being a technological leader exceed the profits earned when both firms have the new technology which, in turn, exceed the profits of being a technological follower. Formally, $\pi^{i}\left(\underline{\gamma}^{i}, \bar{\gamma}^{j}\right)>\pi^{i}\left(\underline{\gamma}^{i}, \underline{\gamma}^{j}\right)>\pi^{i}\left(\bar{\gamma}^{i}, \underline{\gamma}^{j}\right)$ for $i=h, b, i \neq j$. Second, the profits of leading in the technology adoption race exceed the profits earned when both firms have the old technology, which in turn, exceed the profits of being a follower. $\pi^{i}\left(\underline{\gamma}^{i}, \bar{\gamma}^{j}\right)>\pi^{i}\left(\bar{\gamma}^{i}, \bar{\gamma}^{j}\right)>\pi^{i}\left(\bar{\gamma}^{i}, \underline{\gamma}^{j}\right)$ for $i=h, b, i \neq j$.

Thirdly and most importantly, the benefit to a firm of being the leader in adopting the new technology exceeds the benefit to the firm when it's the follower in adopting the new technology.

$$
\pi^{i}\left(\underline{\gamma}^{i}, \bar{\gamma}^{j}\right)-\pi^{i}\left(\bar{\gamma}^{i}, \bar{\gamma}^{j}\right)>\pi^{i}\left(\underline{\gamma}^{i}, \underline{\gamma}^{j}\right)-\pi^{i}\left(\bar{\gamma}^{i}, \underline{\gamma}^{j}\right)>0
$$

Equation (3) is the critical condition that ensures that the two firms, home and firm B, will never want to adopt the new technology at the same moment in time, even if their instantaneous profit functions are identical.

\section{The technology adoption game}

The home firm and the firm in country B strategically choose dates at which to adopt the new technology, $t^{h}$ and $t^{b}$, in order to maximize the discounted present value of net profits. The firm in country A, which already has the new technology, has no strategic choice to make regarding

\footnotetext{
${ }^{13}$ In sections 3.2 and 3.3, I discuss how relaxing the assumption that tariffs are constant over time will alter the results.
} 
technology. It does, however, continue to strategically choose the quantity of output to sell in the home country. The discounted present value of net profits to firm $i=h, b, i \neq j$ depends on whether it is a leader or follower in technology adoption and is given by the following:

$$
V^{i}\left(t^{i}, t^{j}\right)=\left\{\begin{array}{l}
g^{\ell i}\left(t^{i}, t^{j}\right) \text { if } t^{i} \leq t^{j} \\
g^{f i}\left(t^{i}, t^{j}\right) \text { if } t^{i} \geq t^{j}
\end{array}\right.
$$

where

$$
\begin{aligned}
& g^{\ell i}\left(t^{i}, t^{j}\right)=\int_{0}^{t^{i}} e^{-r s} \pi^{i}\left(\bar{\gamma}^{i}, \bar{\gamma}^{j}\right) d s+\int_{t^{i}}^{t^{j}} e^{-r s} \pi^{i}\left(\underline{\gamma}^{i}, \bar{\gamma}^{j}\right) d s+\int_{t^{j}}^{\infty} e^{-r s} \pi^{i}\left(\underline{\gamma}^{i}, \underline{\gamma}^{j}\right) d s-e^{-r t^{i}} C\left(t^{i}\right) \\
& g^{f i}\left(t^{i}, t^{j}\right)=\int_{0}^{t^{j}} e^{-r s} \pi^{i}\left(\bar{\gamma}^{i}, \bar{\gamma}^{j}\right) d s+\int_{t^{j}}^{t^{i}} e^{-r s} \pi^{i}\left(\bar{\gamma}^{i}, \underline{\gamma}^{j}\right) d s+\int_{t^{i}}^{\infty} e^{-r s} \pi^{i}\left(\underline{\gamma}^{i}, \underline{\gamma}^{j}\right) d s-e^{-r t^{i}} C\left(t^{i}\right)
\end{aligned}
$$

The function $g^{\ell i}$ represents the discounted present value of net profits to firm $i$ if it adopts the new technology before firm $j$ does. The first term in $g^{\ell i}$ represents the discounted present value of firm $i$ 's profits over the period in which both firm $i$ and firm $j$ have the old technology. The second term represents the discounted present value of firm i's profits over the period in which it has the new low-cost technology and firm $j$ has the old high-cost technology. The third term is the discounted present value of firm $i$ 's profits over the period in which both firms have the new technology. Finally, the last term represents the discounted present value of installing the new technology at time $t^{i}$. The function $g^{f i}$ differs from $g^{\ell i}$ in that the second term in $g^{f i}$ represents the discounted present value of profits earned for the period in which firm $i$ lags behind firm $j$ in adopting the new technology.

In the next section, I characterize the Nash equilibrium in the technology adoption game under free trade. In section 3.2 I characterize the Nash equilibrium under a safeguard tariff and in section 3.3 I characterize the Nash equilibrium under an antidumping duty. 


\subsection{Technology Adoption under Free Trade}

When the home firm sets tariffs against both countries equal to zero, it experiences an increase in imports from country A and a decrease in imports from country B in the wake of country A's discovery and adoption of the new technology. Moreover, the price of the good in the home country's market will fall. Thus, in a broad sense, the home country is eligible for trade protection under a variety of WTO provisions. When will the home firm and its foreign competitor, firm B, adopt the new technology if the home country maintains a policy of free trade?

The discounted present value of net profits to each firm, $V^{i}$ is strictly concave and continuous in $t^{i}$ for a given $t^{j}$ but is not differentiable at $t^{i}=t^{j}$. The strict concavity and continuity of $g^{\ell i}\left(t^{i}, t^{j}\right)$ and $g^{f i}\left(t^{i}, t^{j}\right)$ imply that each function has a unique maximum that is independent of $t^{j}$.

Definition 1 Let $\hat{t}^{i}=\arg \max g^{\ell i}\left(t^{i}, t^{j}\right)$ and let $\tilde{t}^{i}=\arg \max g^{f i}\left(t^{i}, t^{j}\right)$ for every $t^{j}$ for $i=h, b$, $i \neq j$.

Each firm's optimal dates for technology adoption have two important features. First, because there are larger gains from being the first to adopt the new technology, see (3), the optimal dates of adoption for each firm depend only on the order of adoption. If a firm is the leader, its optimal date is strictly earlier than if it's a follower $\hat{t}^{i}<\tilde{t}^{i}$ for $i=B, H$. Second, the optimal dates for the two firms will differ according to the total size of the worldwide market each firm faces.

Proposition 1 Optimal adoption dates under free trade. Under free trade, the optimal dates for technology adoption by each firm are (a) diffused over time (i.e., $\hat{t}^{i}<\tilde{t}^{i}$ for $i=h, b$ ) and (b) the relationships between the optimal dates of adoption for the two firms can be summarized as follows where $q^{b}=\frac{1}{2}\left(a^{b}-\frac{1}{2}(\bar{\gamma}+\underline{\gamma})\right)$, the average quantity produced for sale in country B:

$$
\begin{array}{ll}
\hat{t}^{b}<\tilde{t}^{b}<\hat{t}^{h}<\tilde{t}^{h} & \text { if } 0<\frac{3}{8}(\bar{\gamma}-\underline{\gamma})<q^{b} \\
\hat{t}^{b}<\tilde{t}^{b}=\hat{t}^{h}<\tilde{t}^{h} & \text { if } q^{b}=\frac{3}{8}(\bar{\gamma}-\underline{\gamma}) \\
\hat{t}^{b}<\hat{t}^{h}<\tilde{t}^{b}<\tilde{t}^{h} & \text { if } 0<q^{b}<\frac{3}{8}(\bar{\gamma}-\underline{\gamma}) \\
\hat{t}^{b}=\hat{t}^{h}<\tilde{t}^{b}=\tilde{t}^{h} & \text { if } 0=q^{b}
\end{array}
$$


Proof:

Part (a): Diffusion over time. For all $t^{j}, \frac{\partial g^{f i}\left(\hat{t}^{i}, t^{j}\right)}{\partial t^{i}}>\frac{\partial g^{\ell i}\left(\hat{t}^{i}, t^{j}\right)}{\partial t^{i}}=0$ by the definition of $\hat{t}^{i}$ and by (3). Since $\frac{\partial g^{f i}\left(\tilde{t}^{i}, t^{j}\right)}{\partial t^{i}}=0$ and $g^{f i}\left(t^{i}, t^{j}\right)$ is strictly concave, then $\hat{t}^{i}<\tilde{t}^{i}$ for $i=h, b$.

Part (b): Ordering of optimal dates. The partial derivatives of $g^{\ell i}$ with respect to $t^{i}$ and of $g^{f i}$ with respect to $t^{i}$ are as follows:

$$
\begin{aligned}
\frac{\partial g^{\ell i}}{\partial t^{i}} & =e^{-r t^{i}}\left[\pi^{i}\left(\bar{\gamma}^{i}, \bar{\gamma}^{j}\right)-\pi^{i}\left(\underline{\gamma}^{i}, \bar{\gamma}^{j}\right)-C^{\prime}\left(t^{i}\right)+r C\left(t^{i}\right)\right] \\
\frac{\partial g^{f i}}{\partial t^{i}} & =e^{-r t^{i}}\left[\pi^{i}\left(\bar{\gamma}^{i}, \underline{\gamma}^{j}\right)-\pi^{i}\left(\underline{\gamma}^{i}, \underline{\gamma}^{j}\right)-C^{\prime}\left(t^{i}\right)+r C\left(t^{i}\right)\right]
\end{aligned}
$$

From the proof of part (a), $\hat{t}^{i}<\tilde{t}^{i}$ for $i=h, b$ in expressions (5), (7), and (8) . Consider expression (5). I need to show $\tilde{t}^{b}<\hat{t}^{h}$.

By definition 1, evaluating (10) for $i=b$ at its optimal value $\tilde{t}^{b}$ implies $-C^{\prime}\left(\tilde{t}^{b}\right)+r C\left(\tilde{t}^{b}\right)=$ $\pi^{b}\left(\underline{\gamma}^{b}, \underline{\gamma}^{h}\right)-\pi^{b}\left(\bar{\gamma}^{b}, \underline{\gamma}^{h}\right)$. Thus, evaluating (9) for $i=h$ at $\tilde{t}^{b}$ yields, $\left.\frac{\partial g^{\ell h}}{\partial t^{h}}\right|_{\tilde{t}^{b}}=e^{-r \tilde{t}^{b}}\left[\left(\pi^{h}\left(\bar{\gamma}^{h}, \bar{\gamma}^{b}\right)-\right.\right.$ $\left.\left.\pi^{h}\left(\underline{\gamma}^{h}, \bar{\gamma}^{b}\right)\right)+\left(\pi^{b}\left(\underline{\gamma}^{b}, \underline{\gamma}^{h}\right)-\pi^{b}\left(\bar{\gamma}^{b}, \underline{\gamma}^{h}\right)\right)\right]>0$ for $q^{b}>\frac{3}{8}(\bar{\gamma}-\underline{\gamma})$. By the strict concavity of $g^{\ell h}$, it follows that $\tilde{t}^{b}<\hat{t}^{h}$.

Turning to expression (7), it is necessary to show (i) $\hat{t}^{b}<\hat{t}^{h}$, (ii) $\hat{t}^{h}<\tilde{t}^{b}$, and (iii) $\tilde{t}^{b}<\tilde{t}^{h}$. From the proof of expression (5), it follows that (ii) is true for $q^{b}<\frac{3}{8}(\bar{\gamma}-\underline{\gamma})$. For (i), by definition 1, evaluating (9) for $i=b$ at $\hat{t}^{b}$ implies $-C^{\prime}\left(\hat{t}^{b}\right)+r C\left(\hat{t}^{b}\right)=\pi^{b}\left(\underline{\gamma}^{b}, \bar{\gamma}^{h}\right)-\pi^{b}\left(\bar{\gamma}^{b}, \bar{\gamma}^{b}\right)$. Substituting this into (9) for $i=h$ yields $\left.\frac{\partial g^{\ell h}}{\partial t^{h}}\right|_{\hat{t}^{b}}>0$ for $q^{b}<\frac{3}{8}(\bar{\gamma}-\underline{\gamma})$. By the strict concavity of $g^{\ell h}$, it follows that $\hat{t}^{b}<\hat{t}^{h}$. For (iii), by definition 1, evaluating (10) for $i=b$ at $\tilde{t}^{b}$ and substituting this expression into (10) for $i=h$ yields $\left.\frac{\partial g^{f h}}{\partial t^{h}}\right|_{\tilde{t}^{b}}>0$ for $q^{b}<\frac{3}{8}(\bar{\gamma}-\underline{\gamma})$. By the strict concavity of $g^{f h}, \tilde{t}^{b}<\tilde{t}^{h}$.

For expression (8), if $q^{b}=0$, then $g^{\ell h}=g^{\ell b}$ and $g^{f h}=g^{f b}$. Thus, the value of $\hat{t}$ that maximizes $g^{\ell h}$ and $g^{\ell b}$ and the value of $\tilde{t}$ that maximizes $g^{f h}$ and $g^{f b}$ must be the same. QED.

Proposition 1 summarizes the relationship between a firm's optimal dates for technology adoption and the size of the worldwide market it faces. Because country B's market is closed to imports and the home country's market is open, if the home country maintains a free trade policy, firm B will serve a larger market and its optimal dates for adoption will precede the home firm's. Because 
country B's market is closed, it can spread its costs of adoption over a larger number of units and thus has an incentive to adopt the technology at relatively early dates. ${ }^{14}$ Intuitively, condition (5) tells us that when the average quantity firm B sells in its own market is sufficiently large relative to the cost savings generated by the new technology, its optimal dates for technology adoption precede those of the home firm. As the size of country B's market decreases, the profit-maximizing quantity firm B produces for its own market decreases, as given by (7), and the gaps between its optimal dates for adoption and the home firm's optimal dates decrease. Finally, when firm B sells no output in its own market, the optimal dates for adoption for the two firms are the same.

Having identified the optimal dates for adoption under different parameter values, I now turn to each firm's best response function. Given the optimal dates of adoption presented in proposition 1 , the best response function of firm i can be written as

$$
t^{i R}\left(t^{j}\right)=\left\{\begin{array}{l}
\hat{t}^{i} \text { if } t^{j}>\bar{t}^{j} \\
\left\{\hat{t}^{i}, \tilde{t}^{i}\right\} \text { if } t^{j}=\bar{t}^{j} \\
\tilde{t}^{i} \text { if } t^{j}<\bar{t}^{j}
\end{array}\right.
$$

for $i=h, b, i \neq j$ and where $\bar{t}^{j}$ is defined as the value of $t^{j}$ such that $g^{\ell i}\left(\hat{t}^{i}, t^{j}\right)=g^{f i}\left(\tilde{t}^{i}, t^{j}\right)$. The best response function of each firm $i=h, b$ consists of the two dates $\left(\hat{t}^{i}\right.$ and $\left.\tilde{t}^{i}\right)$ that are the candidates for maximizing the discounted present value of net profits $V^{i}$. For firm i, the benefit of being a leader in technology adoption is just equal to the benefit of being a follower in technology adoption if its opponent chooses to adopt the new technology at a date $\bar{t}^{j} \in\left(\hat{t}^{i}, \tilde{t}^{i}\right)$. If firm $\mathrm{j}$ chooses to adopt at any time before this cutoff date $\left(t^{j}<\bar{t}^{j}\right)$, then firm i earns a higher discounted present value of net profits when it delays its technology adoption until the relatively late date $\tilde{t}^{i}$. Hence, firm i's best response to firm $\mathrm{j}$ adopting at any date $t^{j}<\bar{t}^{j}$ is to choose to adopt the new technology at the later date, $\tilde{t}^{i}$. Similarly, if firm $\mathrm{j}$ adopts the new technology at any date $t^{j}>\bar{t}^{j}$, the home firm maximizes its discounted present value of net profits by adopting quickly at date $\hat{t}^{i}$.

\footnotetext{
${ }^{14}$ Relaxing the assumption that foreign markets are closed to each other and the home firm causes the equilibrium to change in an obvious way. If the home firm and firm B have the same access to all markets, the size of their worldwide markets will be identical and their optimal dates for technology adoption will be the same. Consequently, there will be two pure strategy Nash equilibria in which either firm can be the first to adopt the new technology.
} 
Proposition 2 Technology Adoption under free trade. In the technology adoption game, there is one pure strategy Nash equilibrium $\left(\hat{t}^{b}, \tilde{t}^{h}\right)$ in which the firm in country $B$ always adopts the new technology first if the quantity firm $B$ sells in country $B$ is sufficiently large, $q^{b}>k^{*}$ where $k^{*} \in$ $\left(0, \frac{3}{8}(\bar{\gamma}-\underline{\gamma})\right)$. There are two pure strategy Nash equilibria $\left(\hat{t}^{b}, \tilde{t}^{h}\right)$ and $\left(\hat{t}^{h}, \tilde{t}^{b}\right)$ in which either firm can be the first to adopt the new technology if the quantity firm B sells in country B is sufficiently small, $q^{b}<k^{*}$.

Proof: Consider two cases.

Case 1: Suppose $q^{b} \geq \frac{3}{8}(\bar{\gamma}-\underline{\gamma})$. Then, $\tilde{t}^{b}<\hat{t}^{h}$ by proposition 1 . Inspection of the best response functions shows that the only possible intersection is at $\left(\hat{t}^{b}, \tilde{t}^{h}\right)$.

Case 2: Suppose $0 \leq q^{b}<\frac{3}{8}(\bar{\gamma}-\underline{\gamma})$. Then $\hat{t}^{b}<\hat{t}^{h}<\tilde{t}^{b}<\tilde{t}^{h}$ by proposition 1 . If $\hat{t}^{h}<\bar{t}^{h}$ and $\bar{t}^{b}<\tilde{t}^{b}$, then the best response functions intersect at $\left(\hat{t}^{b}, \tilde{t}^{h}\right)$ and $\left(\hat{t}^{h}, \tilde{t}^{b}\right)$. By lemma 3 in appendix A, for all $q^{b}<k^{*}, \hat{t}^{h}<\bar{t}^{h}$ and $\bar{t}^{b}<\tilde{t}^{b}$ so there are two pure strategy Nash equilibria. For all $q^{b}>k^{*}, \hat{t}^{h}>\bar{t}^{h}$ or $\bar{t}^{b}>\tilde{t}^{b}$ or both. Thus, inspection of the best response functions shows that the only possible intersection is at $\left(\hat{t}^{b}, \tilde{t}^{h}\right)$. QED.

Two interesting observations can be drawn from proposition 2. First, the order of technology adoption is indeterminate when the foreign firm's domestic market is sufficiently small or does not exist. ${ }^{15}$ This suggests that if a very small country with perfect access to foreign markets keeps its own market completely closed in order to promote an infant industry, it can still lose the technology race. Alternatively, it also suggests a firm in a small country like Korea could beat a firm in a large country like the EU or US in adopting a new technology if the large country allows imports to enter freely. If the Korean market were closed and the US market were open, the Korean firm's worldwide market share would be larger than that of a firm in the US. Thus, in equilibrium, the Korean firm could adopt first. Second, if the foreign firm's closed domestic market is sufficiently large and the home country's market is open, the home firm will always lose the technology race. This could explain why firms in a country like Japan have historically beat American firms in adopting widely-available new technologies during periods when American markets were relatively

\footnotetext{
${ }^{15}$ Intuitively, allowing for pre-emption as in Fudenberg and Tirole (1985) should make the results more extreme. The firm with the larger worldwide market should always adopt the new technology first in equilibrium. If the two firms are identical in terms of the size of their worldwide markets, the indeterminacy in the order of adoption remains.
} 
open to imports and Japanese markets were relatively closed.

\subsection{Technology Adoption under a safeguard tariff}

The home country could respond to the increase in imports from country A that follows firm A's positive technology-shock with a WTO-authorized safeguard tariff. Applying a safeguard tariff in this context is legitimate because it satisfies the two WTO criteria. First, the equilibrium in the instantaneous quantity setting game involves an increase in imports from country A. Second, the domestic firm suffers "injury" in the form of a loss of market share and reduced profits. I follow the WTO rules and model the safeguard as a tariff that is equally applied to imports from all countries. Although the WTO specifies that a safeguard is a temporary tariff that can be imposed for a maximum duration of five years, I simplify the analysis by analyzing a permanent safeguard tariff. $^{16}$

Under a safeguard tariff policy, the home country imposes a positive, non-prohibitive tariff (i.e., $\left.\tau^{s g}<\frac{1}{2}\left(a-3 \gamma^{h}+\gamma^{a}+\gamma^{b}\right)\right)$ on imports from country A and country B, $\tau^{s g}=\tau^{i}$ for $i=A, B$. From the instantaneous profit functions (1) and (2), we can see that the safeguard tariff increases the home firm's instantaneous profits and decreases the foreign firms' profits, regardless of their technology levels. Under a safeguard tariff, for a given $t^{i}$, the discounted present value of profits $V^{i}$ for $i=h, b$ is strictly concave and continuous, but it is not differentiable at $t^{i}=t^{j}$.

Definition 2 Let $\hat{t}^{i, s g}=\arg \max g^{\ell i}\left(t^{i}, t^{j}, \tau^{s g}\right)$ and let $\tilde{t}^{i, s g}=\arg \max g^{f i}\left(t^{i}, t^{j}, \tau^{s g}\right)$ for every $t^{j}$ for $i=h, b, i \neq j$.

The benefit to the home firm of adopting the new technology is larger under a safeguard tariff than it is under free trade both when it's a leader in adopting and when it's a follower, $\pi^{h}\left(\underline{\gamma}^{h}, \gamma^{b}, \tau^{s g}\right)-\pi^{h}\left(\bar{\gamma}^{h}, \gamma^{b}, \tau^{s g}\right)>\pi^{h}\left(\underline{\gamma}^{h}, \gamma^{b}, \tau^{i}=0\right)-\pi^{h}\left(\bar{\gamma}^{h}, \gamma^{b}, \tau^{i}=0\right)$ for $\gamma^{b}=\underline{\gamma}, \bar{\gamma}$ and $i=a, b$. The safeguard tariff raises the marginal cost of exporting to the home country for firms A and B. For the home firm, under Cournot competition, the marginal benefit of reducing its costs is

\footnotetext{
${ }^{16}$ Miyagiwa and Ohno (1995) have shown that if a temporary tariff has a certain minimum duration and an credible, exogenous termination date, it is equivalent to a permanent tariff in terms of providing an incentive for earlier technology adoption.
} 
larger when its competitors' costs are higher. For the firm in country B, the safeguard tariff has the opposite effect. The safeguard tariff leads firm B to export less and, consequently, produce less. Because the fixed cost of technology adoption must now be spread over a smaller quantity of output, firm B will delay technology adoption relative to its optimal date under free trade.

Lemma 1 The home firm's optimal dates for technology adoption under a safeguard tariff are earlier than under free trade, $\hat{t}^{h, s g}<\hat{t}^{h}$ and $\tilde{t}^{h, s g}<\tilde{t}^{h}$. Firm B's optimal dates for adopting the new technology are later under the safeguard tariff than they are under free trade $\hat{t}^{b, s g}>\hat{t}^{b}$ and $\tilde{t}^{b, s g}>\tilde{t}^{b}$.

Proof: From (9), the first order condition of $g^{\ell i}$ with respect to $t^{i}$ can be written $\pi^{i}\left(\underline{\gamma}^{i}, \bar{\gamma}^{j}\right)-$ $\pi^{i}\left(\bar{\gamma}^{i}, \bar{\gamma}^{j}\right)=r C\left(t^{i}\right)-C^{\prime}\left(t^{i}\right)$. By definition $1, \hat{t}^{i}=\arg \max g^{\ell i}$ under free trade for $i=h, b$ and by definition $2 \hat{t}^{i s g}=\arg \max g^{\ell i}\left(t^{i}, t^{j}, \tau^{s g}\right)$ under a safeguard tariff for $i=h, b$. For all nonprohibitive safeguard tariffs, $0<\tau^{s g}<\frac{1}{2}\left(a-3 \gamma^{h}+\gamma^{a}+\gamma^{b}\right)$, the marginal benefit of the new technology is higher under the safeguard tariff for the home firm, $\pi^{h}\left(\underline{\gamma}^{h}, \bar{\gamma}^{b}, \tau^{s g}\right)-\pi^{h}\left(\bar{\gamma}^{h}, \bar{\gamma}^{b}, \tau^{s g}\right)>\pi^{h}\left(\underline{\gamma}^{h}, \bar{\gamma}^{b}, \tau=0\right)-$ $\pi^{h}\left(\bar{\gamma}^{h}, \bar{\gamma}^{b}, \tau=0\right)$ and lower under the safeguard tariff for firm B, $\pi^{b}\left(\underline{\gamma}^{b}, \bar{\gamma}^{h}, \tau^{s g}\right)-\pi^{b}\left(\bar{\gamma}^{b}, \bar{\gamma}^{h}, \tau^{s g}\right)<$ $\pi^{b}\left(\underline{\gamma}^{b}, \bar{\gamma}^{h}, \tau=0\right)-\pi^{b}\left(\bar{\gamma}^{b}, \bar{\gamma}^{h}, \tau=0\right)$. Thus, $\hat{t}^{h, s g}<\hat{t}^{h}$ and $\hat{t}^{b, s g}>\hat{t}^{b}$. From the first order condition of $g^{f i}$ with respect to $t^{i}$, it can be shown that $\tilde{t}^{h, s g}<\tilde{t}^{h}$ and $\tilde{t}^{b, s g}>\tilde{t}^{b}$. QED.

Proposition 3 Optimal dates under a safeguard tariff. Under a safeguard tariff, the relationships among the optimal dates of adoption for the two firms and the relative magnitudes of the home country's safeguard tariff, $\tau^{s g}$, the cost savings generated by the new technology $\frac{3}{8}(\bar{\gamma}-\underline{\gamma})$, and the average quantity sold by firm $B$ in its own market, $q^{b}=\frac{1}{2}\left(a^{b}-\frac{1}{2}(\bar{\gamma}+\underline{\gamma})\right)$ are as follows:

$$
\begin{aligned}
\hat{t}^{b s g}<\tilde{t}^{b s g}<\hat{t}^{h s g}<\tilde{t}^{h s g} & \text { if } \tau^{s g}<\frac{2}{3}\left(q^{b}-\frac{3}{8}(\bar{\gamma}-\underline{\gamma})\right) \\
\hat{t}^{b s g}<\hat{t}^{h s g}<\tilde{t}^{b s g}<\tilde{t}^{h s g} & \text { if } \frac{2}{3}\left(q^{b}-\frac{3}{8}(\bar{\gamma}-\underline{\gamma})\right)<\tau^{s g}<\frac{2}{3} q^{b} \\
\hat{t}^{b s g}=\hat{t}^{h s g}<\tilde{t}^{b s g}=\tilde{t}^{h s g} & \text { if } \tau^{s g}=\frac{2}{3} q^{b} \\
\hat{t}^{h s g}<\hat{t}^{b s g}<\tilde{t}^{h s g}<\tilde{t}^{b s g} & \text { if } \frac{2}{3} q^{b}<\tau^{s g}<\frac{2}{3}\left(q^{b}+\frac{3}{8}(\bar{\gamma}-\underline{\gamma})\right) \\
\hat{t}^{h s g}<\tilde{t}^{h s g}<\hat{t}^{b s g}<\tilde{t}^{b s g} & \text { if } \frac{2}{3}\left(q^{b}+\frac{3}{8}(\bar{\gamma}-\underline{\gamma})\right)<\tau^{s g}
\end{aligned}
$$


Proof: For diffusion over time, $\left(\hat{t}^{i, s g}<\tilde{t}^{i, s g}\right)$, see the proof of proposition 1 (a). For the order of adoption, as for proposition 1(b), the proof relies on the definitions of $\hat{t}^{i s g}$ and $\tilde{t}^{i s g}$ and on the concavity of $g^{\ell i}$ and $g^{f i}$. The full proof is presented in appendix A.

Overall, expressions (12) through (16) show that when the safeguard tariff is relatively small, firm B's optimal dates are earlier; when the safeguard tariff is relatively large, the home firm's optimal dates are earlier.

More precisely, inequality (12) shows that when the additional cost imposed by the safeguard tariff and the reduction in production costs associated with the new technology are small relative to the equilibrium average quantity sold by firm B in its own market, firm B will have optimal adoption dates that are earlier than the home firm. Although the safeguard tariff increases the home firm's domestic market share and decreases firm B's market share, if country B's own market is sufficiently large, it will still have a stronger incentive to adopt relatively early. Equation (14) can be thought of as the breakeven tariff that makes the two firms identical in terms of their worldwide market share. When the safeguard tariff is sufficiently large relative to the average quantity sold by firm B in country B, the safeguard tariff effectively confers a large domestic market share on the home firm and a small share of the home country's market on firm B. This makes the two firms identical in terms of their worldwide market shares. Thus, they have the same incentives to adopt the new technology. As the magnitude of the safeguard tariff increases beyond this breakeven tariff, the home firm's market share increases to the point that its optimal dates precede firm B's.

Because the equilibrium average quantity sold by firm B increases with the size of the market in country B, inequalities (12) through (16) can be interpreted to explain how the safeguard tariff will affect technology adoption by firms in large versus small countries. For example, if country $\mathrm{B}$ is so small that $q^{b}=0$, even a small safeguard tariff causes the home firm's optimal dates to precede firm B's. Conversely, if country B is very large, even a prohibitive safeguard tariff may be too small to cause the home firm's optimal dates to precede firm B's.

As in the case of free trade, the best response function of firm $i$ is given by (11) with the optimal dates for technology adoption under a safeguard tariff given by proposition 3 .

Proposition 4 Technology adoption under a safeguard tariff. In the technology adoption game, if 
the home country's tariff is sufficiently small relative to the average quantity firm B sells in its own market and the cost savings generated by the new technology $\left(\tau^{s g}<\tau_{1}^{*}\right.$ where $\tau_{1}^{*} \in\left(\frac{2}{3}\left(q^{b}-\frac{3}{8}(\bar{\gamma}-\right.\right.$ $\underline{\gamma})$ ), $\left.\frac{2}{3} q^{b}\right)$ ), then the firm in country $B$ adopts the new technology first in the pure strategy Nash equilibrium $\left(\hat{t}^{b s g}, \tilde{t}^{h s g}\right)$. Over an intermediate range of tariffs $\left(\tau_{1}^{*}<\tau^{s g}<\tau_{2}^{*}\right)$, there are two pure strategy Nash equilibria in which either firm can be the first to adopt the new technology $\left(\hat{t}^{h s g}, \tilde{t}^{b s g}\right)$ or $\left(\hat{t}^{b s g}, \tilde{t}^{h s g}\right)$. If the home country's government imposes a safeguard tariff that is sufficiently large relative to the size of country B's market $\left(\tau^{s g}>\tau_{2}^{*}\right.$ where $\tau_{2}^{*} \in\left(\frac{2}{3} q^{b}, \frac{2}{3}\left(q^{b}+\frac{3}{8}(\bar{\gamma}-\underline{\gamma})\right)\right)$, then the home firm adopts the new technology first in the pure strategy Nash equilibrium $\left(\hat{t}^{\text {hsg }}, \tilde{t}^{b s g}\right)$.

The proof of proposition 4 is similar to the proof of proposition 2 and is presented in appendix A.

See figure 2 for a graph of the Nash equilibrium under different values of the tariff. Panel A depicts the Nash equilibrium when the average quantity sold in country B's market is very large relative to the safeguard tariff and the cost savings generated by the new technology. The benefit of technology adoption to firm B is much larger than the benefit of technology adoption to the home firm because firm B's total output is larger. Therefore, firm B is willing to incur a much larger cost in adopting the new technology. Because the cost of technology adoption is decreasing with time, this translates into firm B's willingness to adopt the new technology at a much earlier date. Consequently, in equilibrium, firm B adopts the new technology first.

Figure 2 also indicates how increasing the tariff above threshold values $\left(\tau_{1}^{*}\right.$ and $\left.\tau_{2}^{*}\right)$ can alter the equilibrium order of adoption. Of particular interest is an increase in the size of the tariff from a value just below $\tau_{2}^{*}$ to a value just above this cutoff. For values of $\tau^{s g}<\tau_{2}^{*}$, the two pure-strategy Nash equilibria are presented in panel B of figure 2. In this panel, although the sizes of the worldwide markets served by the two firms are not identical, the tariff is sufficiently large relative to the size of the market in country B that the two firms' total market shares are similar. This means that the benefit of technology adoption is almost the same for the two firms and implies that in equilibrium, either firm can lead in technology adoption. Interestingly, the home country's government can eliminate this indeterminacy by raising the tariff above $\tau_{2}^{*}$ and, thus, increasing the home firm's total market share. For tariffs in the range $\tau^{s g}>\tau_{2}^{*}$, as depicted in panel $\mathrm{C}$, the home firm's market share is so much larger than that of the total market share of firm B that the 
home firm will always adopt the new technology first.

Another question to consider is how does changing the size of a tariff within an interval affect the equilibrium dates of adoption. Figure 3 presents a graph of how changing the size of $\tau^{s g}$ within the interval $\left(\tau_{1}^{*}, \tau_{2}^{*}\right)$ will affect equilibrium adoption dates. In this case, for small increases in the tariff from $\tau$ to $\tau^{\prime}$, there are still two pure-strategy Nash equilibria. However, an increase in the tariff causes the home firm's optimal adoption dates $\left(\hat{t}^{h s g}\right.$ and $\left.\tilde{t}^{h s g}\right)$ to shift forward in time and causes firm B's optimal adoption dates to shift backward in time.

If the home firm is a technological leader, the safeguard tariff will close the gap between the home firm and firm A. If the home firm is a technological follower, the safeguard tariff will close the gap between the home firm and firm B. For firm B, the safeguard tariff reduces the marginal value of the new technology. Thus, it delays technology adoption and opens a gap between firm B and its predecessor in technology adoption.

\subsection{Technology adoption under an antidumping duty}

Lastly, consider what would happen if the home country imposed a permanent country-specific tariff, similar to an antidumping duty, on imports from country A, but imposed no tariff on imports from country B. Under WTO rules, an antidumping duty could be imposed because the low price that would prevail in the home country immediately after the introduction of the new technology in country A could be compared to firm A's historical data on the costs of producing under the old technology in such a way as to show that firm A was pricing below it average historical cost.

A permanent, non-prohibitive tariff on imports from A, (i.e., $\tau^{a d}<\frac{1}{3}(a-\underline{\gamma})$ ), raises the cost to firm A of exporting to the home country. From (1) and (2), we see that this tariff increases the instantaneous profits of the home firm and firm B regardless of their technology levels. Under an antidumping duty, for a given $t^{i}$, the discounted present value of profits $V^{i}$ for $i=h, b$ is strictly concave and continuous, but it is not differentiable at $t^{i}=t^{j}$.

Definition 3 Let $\hat{t}^{i, a d}=\arg \max g^{\ell i}\left(t^{i}, t^{j}, \tau^{a d}\right)$ and let $\tilde{t}^{i, a d}=\arg \max g^{f i}\left(t^{i}, t^{j}, \tau^{a d}\right)$ for every $t^{j}$ for $i=h, b, i \neq j$. 
For both the home firm and firm B, the marginal benefit of adopting the new technology is larger under an antidumping duty than it is under free trade.

Lemma 2 The optimal dates for technology adoption of the home firm and firm B are earlier under a antidumping duty than they are under free trade, $\hat{t}^{i, a d}<\hat{t}^{i}$ and $\tilde{t}^{i, a d}<\tilde{t}^{i}$.

Proof: From (9), the first order condition of $g^{\ell i}$ with respect to $t^{i}$ can be written $\pi^{i}\left(\underline{\gamma}^{i}, \bar{\gamma}^{j}\right)-$ $\pi^{i}\left(\bar{\gamma}^{i}, \bar{\gamma}^{j}\right)=r C\left(t^{i}\right)-C^{\prime}\left(t^{i}\right)$. By definition $1, \hat{t}^{i}=\arg \max g^{\ell i}$ under free trade for $i=h, b$ and by definition $3 \hat{t}^{i a d}=\arg \max g^{\ell i}\left(t^{i}, t^{j}, \tau^{a d}\right)$ under an antidumping duty for $i=h, b$. For all nonprohibitive, permanent antidumping duties against $\mathrm{A}, 0<\tau^{a d}<\frac{1}{3}(a-\underline{\gamma})$, the marginal benefit of the new technology is higher under the antidumping duty for $i=h, b, \pi^{i}\left(\underline{\gamma}^{i}, \bar{\gamma}^{j}, \tau^{a d}\right)-$ $\pi^{i}\left(\bar{\gamma}^{i}, \bar{\gamma}^{i}, \tau^{a d}\right)>\pi^{i}\left(\underline{\gamma}^{i}, \bar{\gamma}^{j}, \tau=0\right)-\pi^{i}\left(\bar{\gamma}^{i}, \bar{\gamma}^{j}, \tau=0\right)$. Thus, $\hat{t}^{i, a d}<\hat{t}^{i}$ for $i=h, b$. From the first order condition of $g^{f i}$ with respect to $t^{i}$, it can be shown that $\tilde{t}^{i, a d}<\tilde{t}^{i}$ for $i=h, b$. QED.

From the instantaneous profit functions (1) and (2), we can see that the profits earned by the home firm and firm B from sales in the home country are identical under an antidumping duty against country A. By targeting its tariff protection against the import surge from country A, the home country inadvertently helps firm B. The antidumping duty generates some (static) rents for the home firm and provides an incentive for the home firm to acquire the new technology earlier than it would under free trade. However, whereas the safeguard tariff conferred a dynamic gain to the home firm by slowing down firm B's technology adoption, the antidumping duty creates a dynamic cost to the home firm by speeding up its rival's technology adoption.

Proposition 5 Optimal dates under an antidumping duty. Under an antidumping duty, the optimal dates for technology adoption by each firm are (a) earlier than they are under free trade but (b) the relative ordering of the optimal dates is the same as that under free trade. 


$$
\begin{aligned}
\hat{t}^{b, a d}<\tilde{t}^{b, a d}<\hat{t}^{h, a d}<\tilde{t}^{h, a d} & \text { if } 0<\frac{3}{8}(\bar{\gamma}-\underline{\gamma})<q^{b} \\
\hat{t}^{b, a d}<\tilde{t}^{b, a d}=\hat{t}^{h, a d}<\tilde{t}^{h, a d} & \text { if } q^{b}=\frac{3}{8}(\bar{\gamma}-\underline{\gamma}) \\
\hat{t}^{b, a d}<\hat{t}^{h, a d}<\tilde{t}^{b, a d}<\tilde{t}^{h, a d} & \text { if } 0<q^{b}<\frac{3}{8}(\bar{\gamma}-\underline{\gamma}) \\
\hat{t}^{b, a d}=\hat{t}^{h, a d}<\tilde{t}^{b, a d}=\tilde{t}^{h, a d} & \text { if } 0=q^{b}
\end{aligned}
$$

Proof: The proof is identical to the proof of proposition 1 except that the instantaneous profits under an antidumping duty $\pi^{i}\left(\gamma^{i}, \gamma^{j}, \tau^{a d}\right)$ replace the instantaneous profits under free trade. Under an antidumping duty, the marginal benefit of technology adoption, $\pi^{i}\left(\underline{\gamma}^{i}, \bar{\gamma}^{j}, \tau^{a d}\right)-\pi^{i}\left(\bar{\gamma}^{i}, \bar{\gamma}^{j}, \tau^{a d}\right)$ increases by the same amount for the home firm and firm $\mathrm{B}\left(\frac{\partial\left(\pi^{i}\left(\underline{\gamma}^{i}, \gamma^{j}, \tau^{a d}\right)-\pi^{i}\left(\bar{\gamma}^{i}, \gamma^{j}, \tau^{a d}\right)\right)}{\partial \tau^{a d}}=\frac{3}{8}(\bar{\gamma}-\underline{\gamma})>\right.$ 0 for $i=h, b$ and $\gamma^{j}=\underline{\gamma}, \bar{\gamma}$. Because the antidumping duty provides the same incentive for early adoption to each firm, it doesn't alter the ordering of the optimal dates, even though it does cause the optimal dates to be earlier than they are under free trade. QED.

As in the case of free trade, the best response function of firm $i$ is given by (11) with the optimal dates for technology adoption under an antidumping duty described by lemma 2 and given by proposition 5 .

Proposition 6 Technology Adoption under an antidumping duty. In the technology adoption game, there is one pure strategy Nash equilibrium $\left(\hat{t}^{b a d}, \tilde{t}^{\text {had }}\right)$ in which the firm in country B always adopts the new technology first if the quantity firm $B$ sells in country $B$ is sufficiently large, $q^{b}>k^{*}$ where $k^{*} \in\left(0, \frac{3}{8}(\bar{\gamma}-\underline{\gamma})\right)$. There are two pure strategy Nash equilibria $\left(\hat{t}^{b a d}, \tilde{t}^{\text {had }}\right)$ and $\left(\hat{t}^{\text {had }}, \tilde{t}^{\text {bad }}\right)$ in which either firm can be the first to adopt the new technology if the quantity firm B sells in country $B$ is sufficiently small, $q^{b} \leq k^{*}$.

Proof: The proof is identical to the proof of proposition 2.

Although the idea that antidumping duties could accelerate technology adoption may appear surprising, it is consistent with the empirical evidence. It is well-known that US steel firms have often lagged behind their foreign competitors in adopting new technologies. Proposition 6 could explain this as either (1) the foreign competitors had larger worldwide markets shares and therefore 
adopted first or (2) the foreign and US firms had similar worldwide market shares, but although either firm could have been the first to adopt the new technology, the foreign firm adopted first and thus, it was an optimal strategy for the US firm to postpone adoption until the price of the new equipment or technology fell further.

Proposition 6 relies on the assumption that the country-specific antidumping duty is a permanent tariff. Or, more precisely, it relies on the assumption that the duration of the antidumping duty is independent of the home firm's behavior. Earlier work by Matsuyama (1990) and Miyagiwa and Ohno (1995) has shown that a temporary tariff whose termination date is endogenous, i.e. will be removed as soon as the domestic firm adopts the new technology, delays technology adoption. In practice, the duration of antidumping protection is supposed to depend on the behavior of foreign exporting firms, not domestic import-competing ones. However, the output and pricing decisions of domestic firms might play a role in the magnitude and duration of antidumping duties. If the duration of antidumping duties depends on domestic firm behavior, Matsuyama's (1990) analysis is applicable and it may be that domestic firms delay technology adoption to maintain protection.

\section{The importing country's welfare}

Section 3 demonstrated that both antidumping duties and safeguard tariffs can alter the technology adoption decisions of firms. We have seen that both safeguard tariffs and antidumping duties can accelerate an import-competing firm's adoption of a new technology. The question that remains is do safeguard tariffs and antidumping duties improve an importing country's welfare?

Analyzing the welfare implications of a tariff in this model is complicated because different equilibria arise under different parameter values. The government's maximization problem will depend on whether the home firm or the firm in country B adopts the new technology first. Moreover, a small change in a safeguard tariff above or below certain threshold values $\left(\tau_{1}^{*}\right.$ and $\left.\tau_{2}^{*}\right)$ can potentially change the equilibrium order of technology adoption. Thus, the government's objective function need not be continuous in the tariff. In this section, I briefly explore the importing country's welfare under antidumping duties and safeguard tariffs for one equilibrium order of adoption. I outline how small changes in tariffs can affect the home country's welfare when the home firm is the first to 
adopt the new technology. This same approach could be used to examine how a safeguard tariff or antidumping duty affects worldwide welfare and see how the two policies generate gains and losses for different groups in the foreign countries.

\subsection{Welfare under a safeguard tariff}

The government's problem in choosing a safeguard tariff in the equilibrium in which the home firm adopts the technology first $\left(\hat{t}^{h, s g}<\tilde{t}^{b, s g}\right)$ is given by:

$$
\begin{aligned}
\max _{\tau^{s g}} W & =\int_{0}^{\hat{t}^{h, s g}} e^{-r s} w\left(\bar{\gamma}^{h}, \bar{\gamma}^{b}, \tau^{s g}\right) d s+\int_{\hat{t}^{h, s g}}^{\hat{t}^{b, s g}} e^{-r s} w\left(\underline{\gamma}^{h}, \bar{\gamma}^{b}, \tau^{s g}\right) d s \\
& +\int_{\hat{t}^{b, s g}}^{\infty} e^{-r s} w\left(\underline{\gamma}^{h}, \underline{\gamma}^{b}, \tau^{s g}\right) d s-e^{-r \hat{t}^{h, s g}} C\left(\hat{t}^{h, s g}\right)
\end{aligned}
$$

where $w(\cdot)$ is the within-period welfare of the home country, equal to the sum of consumer's surplus, profits and tariff revenue.

The change in the home country's welfare with respect to a small change in the safeguard tariff when the home firm adopts the new technology first is:

$$
\frac{d W}{d \tau^{s g}}=\frac{\partial W}{\partial \tau^{s g}}+\frac{\partial{ }^{(+)}}{\partial \hat{t}^{h, s g}} \frac{\partial \hat{t}^{h, s g}}{\partial \tau^{s g}}+\frac{\partial W}{\partial \tilde{t}^{b, s g}} \frac{\partial \tilde{t}^{b, s g}}{\partial \tau^{s g}}>0
$$

Overall, a small increase in the safeguard tariff improves the home country's welfare. This welfare improvement can be broken into three components, a direct effect, a technology incentive effect, and a technology disincentive effect. These effects are described below. The direct effect essentially captures the rent-shifting gains of a safeguard tariff. Because the firms compete on quantity, the home country can improve welfare by imposing a tariff that shifts rents from foreign firms to the home firm and home country's government.

The second term in (22), which I call the technology-incentive component, is also positive. Recall from lemma 1 that the home firm adopts the new technology at an earlier date as the tariff

increases $\frac{\partial \hat{t}^{h, s g}}{\partial \tau^{s g}}<0$. The effect of a change in the date of adoption on the discounted present value 
of welfare can be expanded as follows:

$$
\frac{\partial W}{\partial \hat{t}^{h, s g}}=\overbrace{e^{-r \hat{t}^{h, s g}}}^{(+)} \overbrace{\left[-C^{\prime}\left(\hat{t}^{h, s g}\right)+r C\left(\hat{t}^{h, s g}\right)-\left(w\left(\underline{\gamma}^{h}, \bar{\gamma}^{b}, \tau^{s g}\right)-w\left(\bar{\gamma}^{h}, \bar{\gamma}^{b}, \tau^{s g}\right)\right)\right]}^{(-)}
$$

The difference $w\left(\underline{\gamma}^{h}, \bar{\gamma}^{b}, \tau^{s g}\right)-w\left(\bar{\gamma}^{h}, \bar{\gamma}^{b}, \tau^{s g}\right)$ is the marginal gain in instantaneous welfare associated with the home firm's adoption of the new technology. The term $-C^{\prime}\left(\hat{t}^{h, s g}\right)+r C\left(\hat{t}^{h, s g}\right)$ is the marginal cost of technology adoption at time $\hat{t}^{h, s g}$. Because adoption of the new technology leads to a fall in the domestic price, there are gains to domestic consumers when the home firm adopts the new technology. Because the home firm doesn't internalize these gains to consumers when it chooses its date of adoption, the marginal benefit to the home country of technology adoption exceeds the marginal cost to the home firm of technology adoption. Thus, the term $\frac{\partial W}{\partial \hat{t}^{h, s g}}$ is negative; the discounted present value of welfare increases if the home firm adopts the new technology at an earlier date. As the safeguard tariff causes the home firm to adopt earlier, the overall contribution of the technology incentive component is positive.

The third term in (22), which I call the technology disincentive component, is also positive because the home country's welfare increases when firm B delays its technology adoption. The effect on the home country's welfare of a change in the date of technology adoption by firm B can be expanded as follows.

$$
\frac{\partial W}{\partial \tilde{t}^{b, s g}}=\overbrace{e^{-r \tilde{t}^{b}}}^{(+)} \overbrace{\left[-\left(w\left(\underline{\gamma}^{h}, \underline{\gamma}^{b}, \tau^{s g}\right)-w\left(\underline{\gamma}^{h}, \bar{\gamma}^{b}, \tau^{s g}\right)\right)\right]}^{(+)}
$$

The difference $w\left(\underline{\gamma}^{h}, \underline{\gamma}^{b}, \tau^{s g}\right)-w\left(\underline{\gamma}^{h}, \bar{\gamma}^{b}, \tau^{s g}\right)$ represents the marginal decrease in the home country's instantaneous welfare when firm B adopts the new technology. Although adoption of a new technology by the firm in country B will increase the home country's consumer's surplus, the loss to the home firm's profits is larger. Thus, the term $\frac{\partial W}{\partial \tilde{t}^{b, s g}}>0$. Because the safeguard tariff delays firm B's technology adoption, the overall contribution of the technology disincentive component is positive.

In summary, a safeguard tariff improves the home country's welfare in three ways. First, it shifts rents to the home country. Second, it accelerates technology adoption by the home firm. Third, 
it delays foreign technology adoption. It is interesting that the safeguard tariff, widely perceived as a more "fair" instrument of protection that an antidumping duty, actually generates some of its welfare gains for the home country by slowing down technology adoption in countries that are technologically behind.

\subsection{Welfare under an antidumping duty}

In the equilibrium in which the home firm adopts the new technology before firm B, the home country's government's problem is:

$$
\begin{aligned}
\max _{\tau^{a d}} W & =\int_{0}^{\hat{t}^{h, a d}} e^{-r s} w\left(\bar{\gamma}^{h}, \bar{\gamma}^{b}, \tau^{a d}\right) d s+\int_{\hat{t}^{h, a d}}^{\hat{t}^{b, a d}} e^{-r s} w\left(\underline{\gamma}^{h}, \bar{\gamma}^{b}, \tau^{a d}\right) d s \\
& +\int_{\tilde{t}^{b, a d}}^{\infty} e^{-r s} w\left(\underline{\gamma}^{h}, \underline{\gamma}^{b}, \tau^{a d}\right) d s-e^{-r \hat{t}^{h, a d}} C\left(\hat{t}^{h, a d}\right)
\end{aligned}
$$

where $w(\cdot)$ is the home country's welfare under an antidumping duty against imports from country A.

The change in the home country's welfare with respect to a small change in the antidumping duty is given by the following:

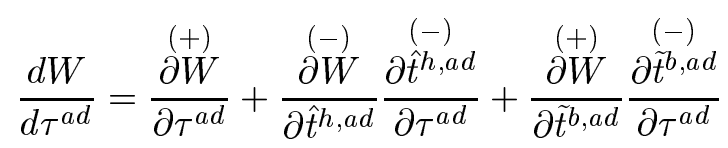

Equation (24) is qualitatively very similar to equation (22), the change in the home country's welfare with respect to a change in the safeguard tariff. Although the magnitudes of the direct effect and the technology incentive effect are different under an antidumping duty, the direction is the same. Both components contribute positively to the home country's welfare. The third term in (24) is now a foreign technology incentive rather than a disincentive. Recall from lemma 2 that the antidumping duty accelerates firm B's technology adoption. Because earlier adoption by firm B reduces the home firm's profits (and the government's tariff revenue) more than it increases consumer's surplus, the term $\frac{\partial W}{\partial \tilde{t}^{b, a d}}$ is positive. Therefore, the foreign technology incentive 
component is negative. Thus, the welfare effect of a small increase in the antidumping duty depends on which terms dominate. As the direct, rent-shifting component is likely to be larger than the other two effects, the overall effect on welfare is likely positive.

Interestingly, the policy favored by domestic import-competing firms, the antidumping duty, appears to offer smaller welfare gains to the importing country than the safeguard tariff. Moreover, although antidumping policy is often criticized as harmful to worldwide welfare, it appears to be less harmful to foreign firms than safeguards policy.

\section{Conclusion}

This paper explores how the breadth of trade protection affects the technology adoption decisions of domestic import-competing and foreign exporting firms. I find that targeted countryspecific tariffs, like antidumping duties, can close the technology gap that arises when an exporting firm in one country discovers and implements a new technology. Importantly, the antidumping duty accelerates adoption by both the protected domestic firm and its foreign competitors. In contrast, safeguard tariffs can close the technology gap for domestic import-competing firms, but also open the gap for foreign exporting firms.

One way to understand the historical pattern of the US industry's failure to innovate is to argue that in selectively restricting imports from technologically-superior countries like the EU and Japan, the US opened its market to firms in smaller countries that were technologically behind. By increasing the market share of firms in countries like Korea, Turkey, and Brazil, the US increased the incentive for firms in these countries to develop new, innovative steel plants.

A more important policy conclusion to be drawn from this paper is that broad safeguard tariffs create incentives for foreign firms to delay their technology adoption relative to what they would choose under free trade or an antidumping duty. Interestingly, an across-the-board tariff increase could result in a loss to worldwide welfare by delaying the adoption of a new technology in other exporting countries. This tends to lend merit to the argument of many countries that lobbied for the creation of country-specific safeguards tariffs during the Uruguay round. Countries that have small domestic markets and are technological followers could find themselves falling even further 
behind technologically if they are subjected to a safeguards tariff which was instituted in the wake of their competitor's technological improvement. Policymakers have been dismayed with the variety of negative welfare consequences of antidumping duties and have suggested that safeguard tariffs would somehow be less prone to political abuse and would distort trade flows less than antidumping duties. This paper suggests that multicountry safeguard tariffs are not a panacea. 


\section{Appendix A: Proofs}

Lemma 3 There exists a $k^{*} \in\left(0, \frac{3}{8}(\bar{\gamma}-\underline{\gamma})\right)$ such that $\bar{t}^{h}<\hat{t}^{h}$ and $\tilde{t}^{b}<\bar{t}^{b}$ if $q^{b}<k^{*}$.

Proof: Define $k^{*}=\min \left[k^{1 *}, k^{2 *}\right]$. The instantaneous profit function of firm B and the first order conditions for $g^{\ell b}$ and $g^{f b}$ imply that $\frac{\partial \hat{t}^{b}}{\partial q^{b}}<0$ and $\frac{\partial \tilde{t}^{b}}{\partial q^{b}}<0$. Thus, by definition $\bar{t}^{h}$ is a decreasing function of $q^{b}$. For all $q^{b} \in\left(0, \frac{3}{8}(\bar{\gamma}-\underline{\gamma})\right), \hat{t}^{b}<\hat{t}^{h}<\tilde{t}^{b}$. By definition of $V^{h}$, definition 1 and definition of $\bar{t}^{b}, \frac{\partial \hat{t}^{h}}{\partial q^{b}}=0$ and $\frac{\partial \bar{t}^{b}}{\partial q^{b}}=0$. By the continuity and monotonicity of $\hat{t}^{h}$, it follows that there exists some $q^{b}=k^{1 *}-\epsilon$ such that $\hat{t}^{h}=\bar{t}^{h}$. Thus, for $q^{b}>k^{1 *}, \hat{t}^{h}>\bar{t}^{h}$. By the continuity and monotonicity of $\tilde{t}^{b}$, it follows that there exists some $q^{b}=k^{2 *}-\epsilon$ such that $\tilde{t}^{b}=\bar{t}^{b}$. Thus, for $q^{b}>k^{2 *}, \bar{t}^{b}>\tilde{t}^{b}$. QED.

\section{Proof of proposition 3}

(b) Order of optimal dates under a safeguard tariff. Let $\tau_{1}=\frac{2}{3}\left[q^{b}-\frac{3}{8}(\bar{\gamma}-\underline{\gamma})\right], \tau_{2}=\frac{2}{3} q^{b}$, and let $\tau_{3}=\frac{2}{3}\left[q^{b}+\frac{3}{8}(\bar{\gamma}-\underline{\gamma})\right]$. From the proof of part (a), we know that $\hat{t}^{b s g}<\tilde{t}^{b s g}$ and $\hat{t}^{h s g}<\tilde{t}^{h s g}$ for expressions (12), (13), (14), (15) and (16). Taking each expression in turn, consider expression (12). I need to show $\tilde{t}^{b s g}<\hat{t}^{h s g}$. By definition 1, evaluating the partial derivative of $g^{f b}$ with respect to $t^{b}(10)$ at its optimal value $\tilde{t}^{b s g}$ implies $-C^{\prime}\left(\tilde{t}^{b s g}\right)+r C\left(\tilde{t}^{b s g}\right)=\pi^{B}\left(\underline{\gamma}^{B}, \underline{\gamma}^{H}\right)-\pi^{B}\left(\bar{\gamma}^{B}, \underline{\gamma}^{H}\right)$. Thus, evaluating $\frac{\partial g^{\ell h}}{\partial t^{h}}$ at $\tilde{t}^{b s g}$ yields $\left.\frac{\partial g^{\ell h}}{\partial t^{h}}\right|_{\tilde{t}^{b s g}}=e^{-r \tilde{t}^{b s g}}\left[\left(\pi^{H}\left(\bar{\gamma}^{H}, \bar{\gamma}^{B}\right)-\pi^{H}\left(\underline{\gamma}^{H}, \bar{\gamma}^{B}\right)\right)+\left(\pi^{B}\left(\underline{\gamma}^{B}, \underline{\gamma}^{H}\right)-\right.\right.$ $\left.\left.\pi^{H}\left(\bar{\gamma}^{B}, \underline{\gamma}^{H}\right)\right)\right]>0$ for $\tau^{s g}<\tau_{1}$. By the strict concavity of $g^{\ell h}(\cdot)$, it follows that $\tilde{t}^{b s g}<\hat{t}^{h s g}$ for $\tau^{s g}<\tau_{1}$.

Turning to expression (13), it is necessary to show (i) $\hat{t}^{b s g}<\hat{t}^{h s g}$, (ii) $\hat{t}^{h s g}<\tilde{t}^{b s g}$, and (iii) $\tilde{t}^{b s g}<\tilde{t}^{h s g}$. From the proof of expression (12), it follows that (ii) is true for $\tau^{s g}>\tau_{1}$. For (i), by definition 1, evaluating (9) for $i=b$ at $\hat{t}^{b s g}$ implies $-C^{\prime}\left(\hat{t}^{b s g}\right)+r C\left(\hat{t}^{b s g}\right)=\pi^{b}\left(\underline{\gamma}^{b}, \bar{\gamma}^{h}\right)-\pi^{b}\left(\bar{\gamma}^{b}, \bar{\gamma}^{b}\right)$. Thus, substitution and direct calculation imply $\left.\frac{\partial g^{\ell h}}{\partial t^{h}}\right|_{\hat{t}^{b s}}>0$ for $\tau^{s g}<\tau_{2}$. By the strict concavity of $g^{\ell H}(\cdot)$, it follows that $\hat{t}^{b s g}<\hat{t}^{h s g}$. For (iii), the partial derivative of $g^{f h}$ with respect to $t^{h}$ and the partial derivative of $g^{f b}$ with respect to $t^{b}$ is given by (10) for $i=h$ and $b$, respectively. By definition 1, evaluating (10) for $i=b$ at $\tilde{t}^{b s g}$ and substituting this expression into (10) for $i=h$ enables one to evaluate $\left.\frac{\partial g^{f h}}{\partial t^{h}}\right|_{\tilde{t}^{b s g}}>0$ for $\tau^{s g}<\tau_{2}$. By the strict concavity of $g^{f h}, \tilde{t}^{b s g}<\tilde{t}^{h s g}$.

Turning to expression (15), I must show (iv) $\hat{t}^{h s g}<\hat{t}^{b s g}$, (v) $\hat{t}^{b s g}<\tilde{t}^{h s g}$, and (vi) $\tilde{t}^{h s g}<\tilde{t}^{b s g}$. From the proof of expression (13) (i), (iv) is true for $\tau^{s g}>\tau_{2}$ and from the proof of (13) (iii), (vi) 
is true for $\tau^{s g}>\tau_{2}$. For (v), recall that the partial of $g^{\ell b}$ with respect to $t^{b}$ is given by (9) for $i=b$ and the partial of $g^{f h}$ with respect to $t^{h}$ is given by (10) for $i=h$. By definition 1 , evaluating $\frac{\partial g^{\ell b}}{\partial t^{b}}$ at $\hat{t}^{b s g}$ and substituting this expression into (9) for $i=h$ yields $\left.\frac{\partial g^{f h}}{\partial t^{h}}\right|_{\hat{t}^{b s g}}>0$ for $\tau^{s g}<\tau_{3}$. By the strict concavity of $g^{f h}, \hat{t}^{b s g}<\tilde{t}^{h s g}$.

Finally, turning to expression (16), I need to show $\tilde{t}^{h s g}<\hat{t}^{b s g}$. From the proof of expression (15) (v), this holds for $\tau^{s g}>\tau_{3}$. QED.

\section{Proof of proposition 4}

I proceed by analyzing a series of cases.

Case 1: Suppose $\tau^{s g}<\tau_{1}<\tau_{1}^{*}$. Then, $\tilde{t}^{b, s g}<\hat{t}^{h, s g}$ by proposition 3. Inspection of the best response functions shows that the only possible intersection is at $\left(\hat{t}^{b, s g}, \tilde{t}^{h, s g}\right)$.

Case 2: Suppose $\tau^{s g}>\tau_{3}>\tau_{2}^{*}$. Then, $\tilde{t}^{h, s g}<\hat{t}^{b, s g}$ by proposition 3 and the only possible intersection of the best response functions is at $\left(\hat{t}^{h, s g}, \tilde{t}^{b, s g}\right)$.

Case 3: Suppose $\tau_{1}<\tau^{s g}<\tau_{2}$. Then $\hat{t}^{b, s g}<\hat{t}^{h, s g}<\tilde{t}^{b, s g}<\tilde{t}^{h, s g}$ by proposition 3. By lemma 4, for smaller tariffs $\left(\tau^{s g}<\tau_{1}^{*}\right)$ within this interval, $\hat{t}^{h, s g}>\bar{t}^{h, s g}$. Inspection of the best response functions reveals that the only intersection for $\hat{t}^{h, s g}>\bar{t}^{h, s g}$ occurs at $\left(\hat{t}^{b, s g}, \tilde{t}^{h, s g}\right)$. By lemma 4 , for larger tariffs $\left(\tau^{s g}>\tau_{1}^{*}\right)$ within this interval, $\hat{t}^{h, s g}<\bar{t}^{h, s g}$. Thus, there are two pure strategy Nash equilibria, $\left(\hat{t}^{b, s g}, \tilde{t}^{h, s g}\right)$ and $\left(\hat{t}^{h, s g}, \tilde{t}^{b, s g}\right)$.

Case 4: Suppose $\tau_{2}<\tau^{s g}<\tau_{3}$. Then $\hat{t}^{h, s g}<\hat{t}^{b, s g}<\tilde{t}^{h, s g}<\tilde{t}^{b, s g}$ by proposition 3. By lemma 5 , for larger tariffs $\left(\tau^{s g}>\tau_{2}^{*}\right)$ within this interval, $\bar{t}^{b, s g}<\hat{t}^{b, s g}$ and the best response functions can only intersect at $\left(\hat{t}^{b, s g}, \tilde{t}^{h, s g}\right)$. By lemma 5 , for smaller tariffs $\left(\tau^{s g}<\tau_{2}^{*}\right)$ within this interval, $\hat{t}^{b, s g}<\bar{t}^{b, s g}$. Thus, there are two pure strategy Nash equilibria, $\left(\hat{t}^{b, s g}, \tilde{t}^{h, s g}\right)$ and $\left(\hat{t}^{h, s g}, \tilde{t}^{b, s g}\right)$. QED.

Lemma 4 There exists a $\tau_{1}^{*} \in\left(\tau_{1}, \tau_{2}\right)$ such that $\bar{t}^{h, s g}<\hat{t}^{h, s g}$ if $\tau^{s g}<\tau_{1}^{*}$ and $\hat{t}^{h, s g}<\bar{t}^{h, s g}$ if $\tau^{s g}>\tau_{1}^{*}$.

Proof: For all $\tau^{s g} \in\left(\tau_{1}, \tau_{2}\right), \hat{t}^{b, s g}<\hat{t}^{h, s g}<\tilde{t}^{b, s g}$ by proposition 3 . Further, $\hat{t}^{h, s g}=\tilde{t}^{b, s g}$ at $\tau_{1}$ and $\hat{t}^{h, s g}=\hat{t}^{b, s g}$ at $\tau_{2}$ by proposition 3 . By the definition of $V^{h}(\cdot)$ and definition $1, \frac{\partial \hat{t}^{h}}{\partial \tau^{s g}}<0$. From the best response function (11), we know $\bar{t}^{h, s g} \in\left(\hat{t}^{b, s g}, \tilde{t}^{b, s g}\right) \forall \tau^{s g}$. By the continuity and monotonicity 
of $\bar{t}^{h, s g}$, it follows that there exists at $\tau_{1}^{*} \in\left(\tau_{1}, \tau_{2}\right)$ such that $\hat{t}^{h, s g}=\bar{t}^{h, s g}$. For $\tau^{s g}<\tau_{1}^{*}, \hat{t}^{h, s g}>\bar{t}^{h, s g}$ and for $\tau^{s g}>\tau_{1}^{*}, \hat{t}^{h, s g}<\bar{t}^{h, s g}$. QED.

Lemma 5 There exists a $\tau_{1}^{*} \in\left(\tau_{2}, \tau_{3}\right)$ such that $\hat{t}^{b, s g}<\bar{t}^{b, s g}$ if $\tau^{s g}<\tau_{2}^{*}$ and $\bar{t}^{b, s g}<\hat{t}^{b, s g}$ if $\tau^{s g}>\tau_{2}^{*}$.

Proof: For all $\tau^{s g} \in\left(\tau_{2}, \tau_{3}\right), \hat{t}^{h, s g}<\hat{t}^{b, s g}<\tilde{t}^{h, s g}$ by proposition 3 . Further, $\hat{t}^{b, s g}=\hat{t}^{h, s g}$ at $\tau_{2}$ and $\hat{t}^{b, s g}=\tilde{t}^{h, s g}$ at $\tau_{3}$ by proposition 3 . By the definition of $V^{b}(\cdot)$ and definition $1, \frac{\partial \hat{t}^{b}}{\partial \tau}>0$. From the best response function (11), we know $\bar{t}^{b, s g} \in\left(\hat{t}^{h, s g}, \tilde{t}^{h, s g}\right) \forall \tau^{s g}$. By the continuity and monotonicity of $\bar{t}^{b, s g}$, it follows that there exists at $\tau_{2}^{*} \in\left(\tau_{2}, \tau_{3}\right)$ such that $\hat{t}^{b, s g}=\bar{t}^{b, s g}$. For $\tau^{s g}<\tau_{2}^{*}, \hat{t}^{b, s g}<\bar{t}^{b, s g}$ and for $\tau^{s g}>\tau_{2}^{*}, \hat{t}^{b, s g}>\bar{t}^{b, s g}$. QED. 
Figure 1: Trade Flows in the Model

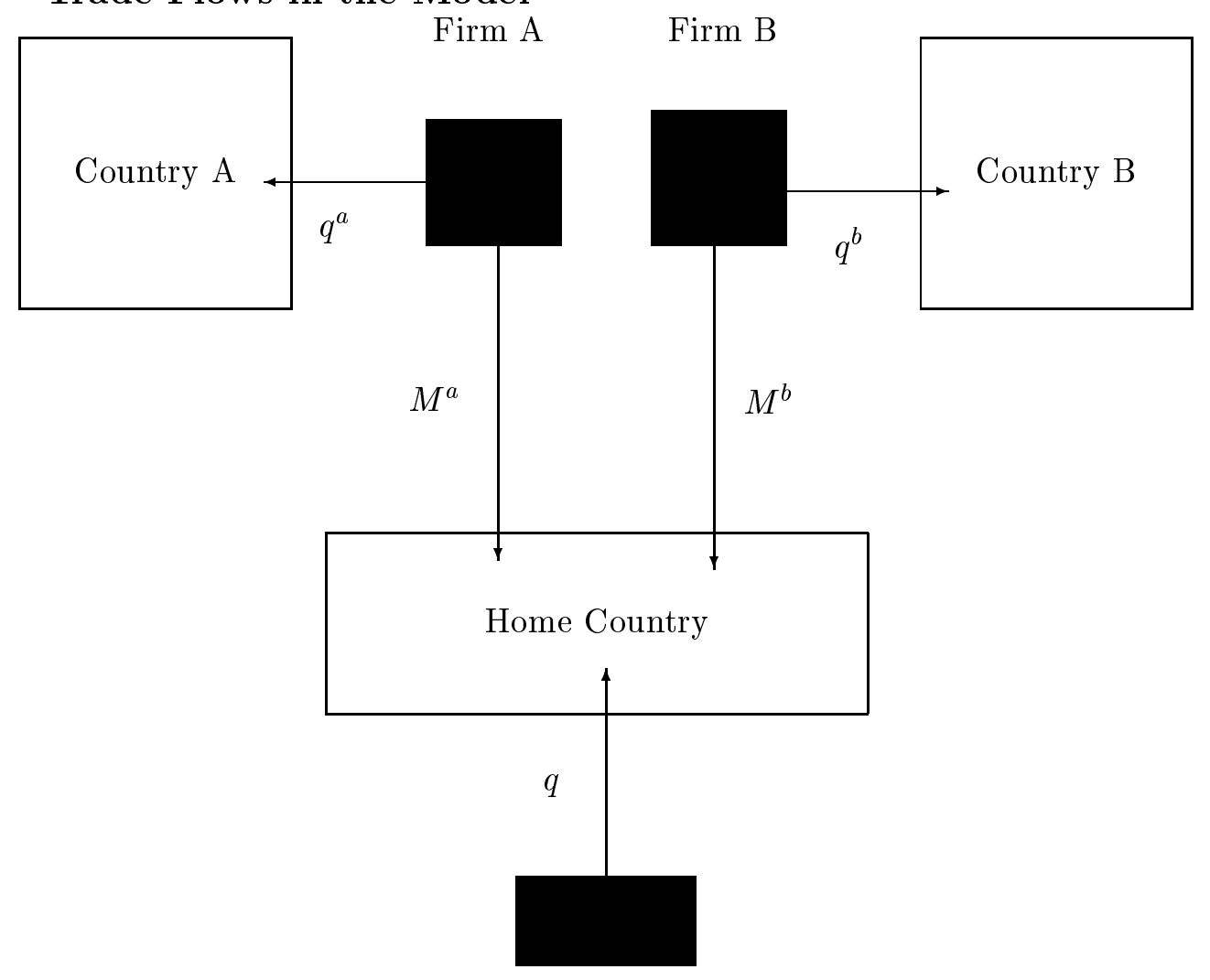

Home Firm 
Figure 2: Nash Equilibria under a safeguard tariff
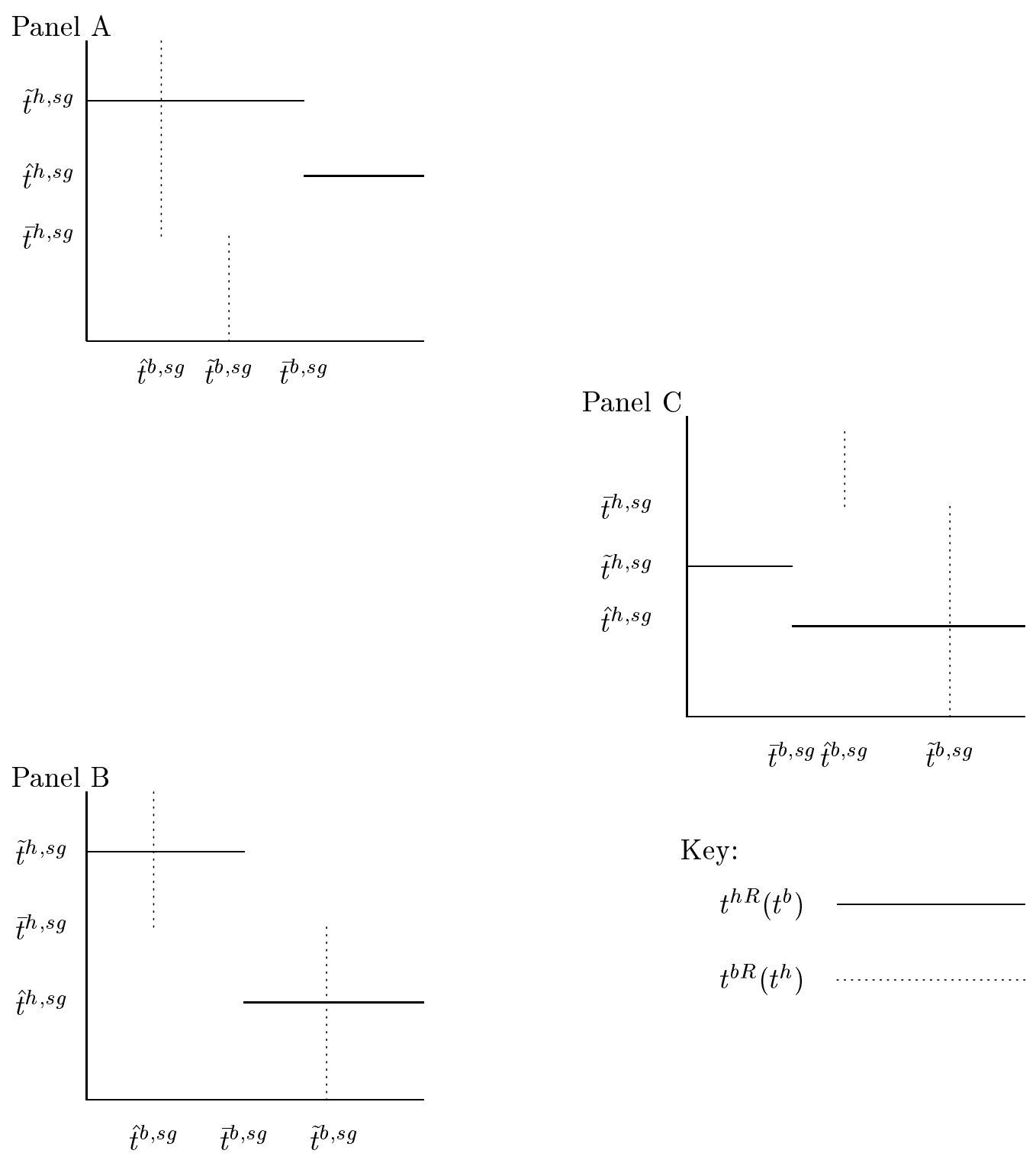

Key:

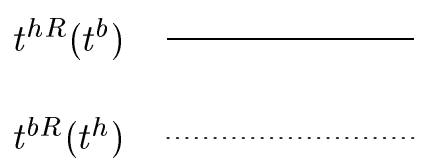

Panel A: One pure-strategy Nash equilibrium at $\left(\hat{t}^{b}, \tilde{t}^{h}\right)$ for $\tau^{s g}<\tau_{1}^{*}$

Panel B: Two pure-strategy Nash equilibria at $\left(\hat{t}^{b}, \tilde{t}^{h}\right)$ and $\left(\hat{t}^{h}, \tilde{t}^{b}\right)$ for $\tau_{1}^{*}<\tau^{s g}<\tau_{2}^{*}$

Panel C: One pure-strategy Nash equilibrium at $\left(\hat{t}^{h}, \tilde{t}^{b}\right)$ for $\tau_{2}^{*}<\tau^{s g}$ 
Figure 3: A small change in the safeguard tariff

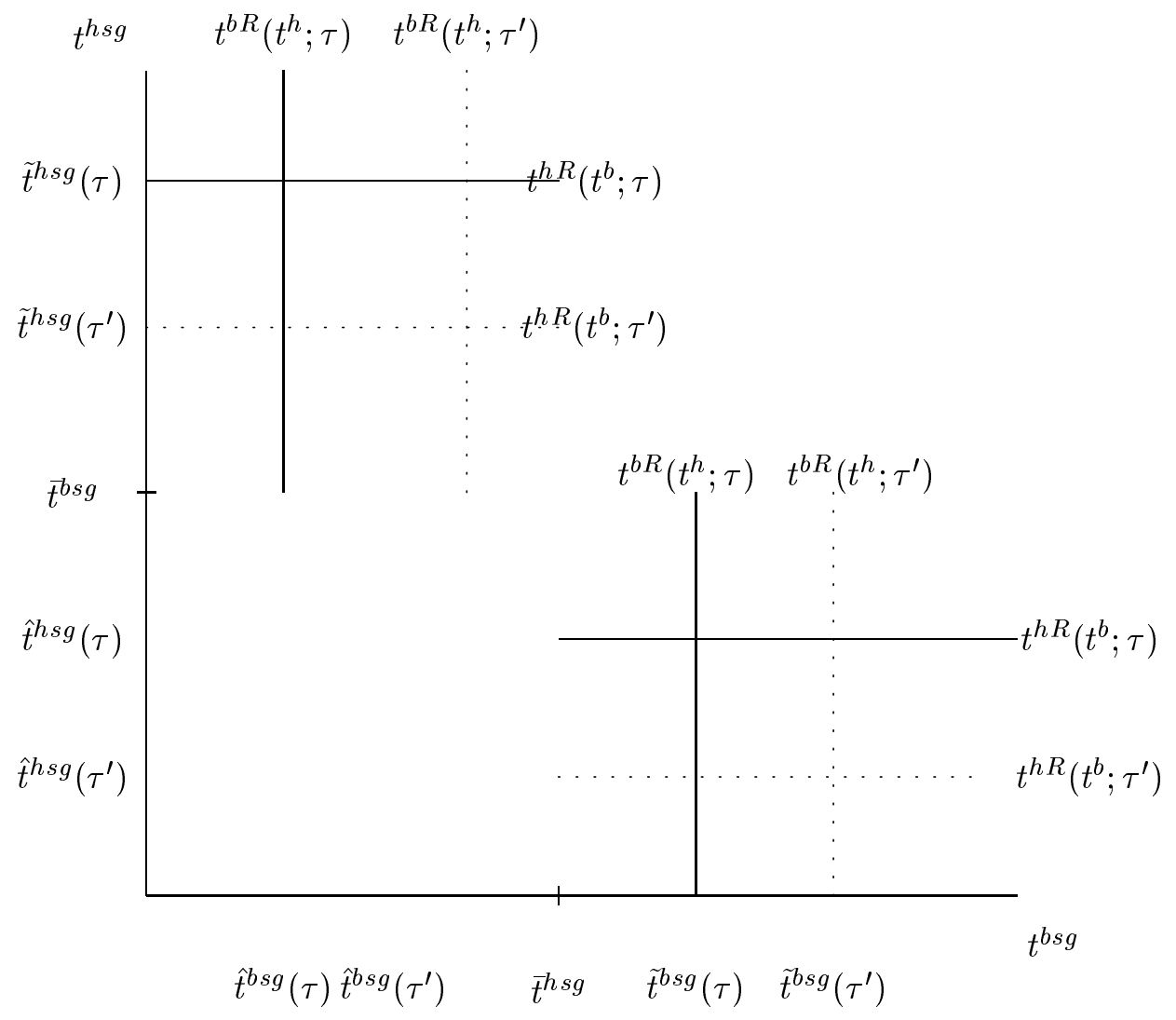




\section{References}

[1] Anderson, James E. 1992. "Domino Dumping, I: Competitive Exporters." American Economic Review, 82:65-83.

[2] Bagwell, Kyle and Staiger, Robert W. 1999. "An Economic Theory of GATT." American Economic Review, 89:215-248.

[3] Bagwell, Kyle and Staiger, Robert W. 1990. "A Theory of Managed Trade." American Economic Review, 80:779-795.

[4] Baldwin, Robert. 1985. The Political Economy of US Import Policy. Cambridge: The MIT Press.

[5] Bhala, Raj. 1996. "Rethinking Antidumping Law." 29 George Washington Journal of International Law and Economics Issue I in International Trade Law: Cases and Materials, Raj Bhala, ed. Charlottesville, VA: Michie Law Publishers.

[6] Clarida, Richard 1993. "Entry, Dumping, and Shakeout." American Economic Review, $83: 180-202$.

[7] Ethier, Wilfred J. 1998. "Regionalism in a Multilateral World." Journal of Political Economy, 106:1214-1245.

[8] Ethier, Wilfred J. 1998. "Unilateralism in a Multilateral World." University of Pennsylvania and Institute of Social and Economic Research working paper.

[9] Finger, J.M.; Hall, H. Keith; and Nelson, Douglas R. 1982. "The Political Economy of Administered Protection." American Economic Review, 452-466.

[10] Fischer, Ronald D. and Prusa, Thomas J. 1999. "Contingent Protection as Better Insurance." NBER Working Paper \# 6933.

[11] Fudenberg, Drew and Tirole, Jean 1985. "Preemption and Rent Equalization in the Adoption of New Technology" Review of Economic Studies, 383-401. 
[12] Gallaway, Michael P., Blonigen, Bruce A. and Flynn, Joseph E. 2000. "Welfare Costs of the US Antidumping and Countervailing Duty Laws." Journal of International Economics.

[13] Gruenspecht, Howard K. 1988. "Dumping and Dynamic Competition." Journal of International Economics, 25: 225-248.

[14] Hansen, Wendy L. and Prusa, Thomas J. 1995. "The Road Most Taken: the Rise of Title VII Protection." World Economy, 295-313.

[15] Harley-Davidson Motor Company 2000. "Harley-Davidson: Background and History." Pamphlet available at www.harley-davidson.com/company/downloads/background.pdf.

[16] Hartigan, James C. 1996. "Predatory Dumping." The Canadian Journal of Economics, 29:228-239.

[17] Jackson, John H. 1989, 1997. The World Trading System: Law and Policy of International Economic Relations, First and Second Editions. Cambridge: The MIT Press.

[18] Matsuyama, Kiminori 1990. "Perfect Equilibria in a Trade Liberalization Game." American Economic Review, 80:480-492.

[19] Miyagiwa, Kaz and Ohno, Yuka 1995. "Closing the Technology Gap Under Protection." American Economic Review, 85:755-770.

[20] Miyagiwa, Kaz and Ohno, Yuka 1999. "Credibility of Protection and Incentives to Innovate." International Economic Review, 40:143-163.

[21] Moore, Michael O. 1996. "The Rise and Fall of Big Steel's Influence on US Trade Policy," in The Political Economy of Trade Protection, Anne O. Krueger, ed. Chicago: University of Chicago Press.

[22] Oster, Sharon. 1982. "The Diffusion of Innovation among Steel Firms: The Basic Oxygen Furnace." Bell Journal of Economics, 13:45-56.

[23] OECD Steel Committee. 1971-2000. Iron and Steel Industry in [year]: Industrie Siderurgique en [year]. Paris: Secretary-General of the OECD. 
[24] Prusa, Thomas J. 2001. "On the Spread and Impact of Antidumping." Canadian Journal of Economics, 34:591-611.

[25] Reinganum, Jennifer F. 1981a. "On the Diffusion of New Technology: A Game Theoretic Approach." Review of Economic Studies, 395-405.

[26] Reinganum, Jennifer F. 1981b. "Market Structure and the Diffusion of New Technology." Bell Journal of Economics, 618-624.

[27] Staiger, Robert W. and Wolak, Frank A. 1994. "Measuring Industry-Specific Protection: Antidumping in the United States." Brookings Papers on Economic Activity, 51-118.

[28] United States International Trade Commission. February 1, 1983. "Report to the President on Investigation TA-201-47: Heavyweight Motorcycles." 


\section{Working Paper Series}

A series of research studies on regional economic issues relating to the Seventh Federal Reserve District, and on financial and economic topics.

Extracting Market Expectations from Option Prices:

WP-99-1

Case Studies in Japanese Option Markets

Hisashi Nakamura and Shigenori Shiratsuka

Measurement Errors in Japanese Consumer Price Index

WP-99-2

Shigenori Shiratsuka

Taylor Rules in a Limited Participation Model

WP-99-3

Lawrence J. Christiano and Christopher J. Gust

Maximum Likelihood in the Frequency Domain: A Time to Build Example

WP-99-4

Lawrence J.Christiano and Robert J. Vigfusson

Unskilled Workers in an Economy with Skill-Biased Technology

WP-99-5

Shouyong Shi

Product Mix and Earnings Volatility at Commercial Banks:

WP-99-6

Evidence from a Degree of Leverage Model

Robert DeYoung and Karin P. Roland

School Choice Through Relocation: Evidence from the Washington D.C. Area

WP-99-7

Lisa Barrow

Banking Market Structure, Financial Dependence and Growth:

International Evidence from Industry Data

WP-99-8

Nicola Cetorelli and Michele Gambera

Asset Price Fluctuation and Price Indices

WP-99-9

Shigenori Shiratsuka

Labor Market Policies in an Equilibrium Search Model

WP-99-10

Fernando Alvarez and Marcelo Veracierto

Hedging and Financial Fragility in Fixed Exchange Rate Regimes

WP-99-11

Craig Burnside, Martin Eichenbaum and Sergio Rebelo

Banking and Currency Crises and Systemic Risk: A Taxonomy and Review

WP-99-12

George G. Kaufman

Wealth Inequality, Intergenerational Links and Estate Taxation

WP-99-13

Mariacristina De Nardi

Habit Persistence, Asset Returns and the Business Cycle

WP-99-14

Michele Boldrin, Lawrence J. Christiano, and Jonas D.M Fisher

Does Commodity Money Eliminate the Indeterminacy of Equilibria?

WP-99-15 Ruilin Zhou

A Theory of Merchant Credit Card Acceptance

WP-99-16 Sujit Chakravorti and Ted To 


\section{Working Paper Series (continued)}

Who's Minding the Store? Motivating and Monitoring Hired Managers at

WP-99-17 Small, Closely Held Firms: The Case of Commercial Banks

Robert DeYoung, Kenneth Spong and Richard J. Sullivan

Assessing the Effects of Fiscal Shocks

WP-99-18

Craig Burnside, Martin Eichenbaum and Jonas D.M. Fisher

Fiscal Shocks in an Efficiency Wage Model

WP-99-19

Craig Burnside, Martin Eichenbaum and Jonas D.M. Fisher

Thoughts on Financial Derivatives, Systematic Risk, and Central

WP-99-20

Banking: A Review of Some Recent Developments

William C. Hunter and David Marshall

Testing the Stability of Implied Probability Density Functions

WP-99-21

Robert R. Bliss and Nikolaos Panigirtzoglou

Is There Evidence of the New Economy in the Data?

WP-99-22

Michael A. Kouparitsas

A Note on the Benefits of Homeownership

WP-99-23

Daniel Aaronson

The Earned Income Credit and Durable Goods Purchases

WP-99-24

Lisa Barrow and Leslie McGranahan

Globalization of Financial Institutions: Evidence from Cross-Border

WP-99-25

Banking Performance

Allen N. Berger, Robert DeYoung, Hesna Genay and Gregory F. Udell

Intrinsic Bubbles: The Case of Stock Prices A Comment

WP-99-26

Lucy F. Ackert and William C. Hunter

Deregulation and Efficiency: The Case of Private Korean Banks

WP-99-27

Jonathan Hao, William C. Hunter and Won Keun Yang

Measures of Program Performance and the Training Choices of Displaced Workers

WP-99-28

Louis Jacobson, Robert LaLonde and Daniel Sullivan

The Value of Relationships Between Small Firms and Their Lenders

WP-99-29

Paula R. Worthington

Worker Insecurity and Aggregate Wage Growth

WP-99-30

Daniel Aaronson and Daniel G. Sullivan

Does The Japanese Stock Market Price Bank Risk? Evidence from Financial

WP-99-31

Firm Failures

Elijah Brewer III, Hesna Genay, William Curt Hunter and George G. Kaufman

Bank Competition and Regulatory Reform: The Case of the Italian Banking Industry

WP-99-32

Paolo Angelini and Nicola Cetorelli 


\section{Working Paper Series (continued)}

Dynamic Monetary Equilibrium in a Random-Matching Economy

WP-00-1

Edward J. Green and Ruilin Zhou

The Effects of Health, Wealth, and Wages on Labor Supply and Retirement Behavior

WP-00-2

Eric French

Market Discipline in the Governance of U.S. Bank Holding Companies:

WP-00-3

Monitoring vs. Influencing

Robert R. Bliss and Mark J. Flannery

Using Market Valuation to Assess the Importance and Efficiency

of Public School Spending

WP-00-4

Lisa Barrow and Cecilia Elena Rouse

Employment Flows, Capital Mobility, and Policy Analysis

WP-00-5

Marcelo Veracierto

Does the Community Reinvestment Act Influence Lending? An Analysis

of Changes in Bank Low-Income Mortgage Activity

WP-00-6

Drew Dahl, Douglas D. Evanoff and Michael F. Spivey

Subordinated Debt and Bank Capital Reform

WP-00-7

Douglas D. Evanoff and Larry D. Wall

The Labor Supply Response To (Mismeasured But) Predictable Wage Changes

WP-00-8

Eric French

For How Long Are Newly Chartered Banks Financially Fragile?

WP-00-9

Robert DeYoung

Bank Capital Regulation With and Without State-Contingent Penalties

David A. Marshall and Edward S. Prescott

WP-00-10

Why Is Productivity Procyclical? Why Do We Care?

WP-00-11

Susanto Basu and John Fernald

Oligopoly Banking and Capital Accumulation

WP-00-12

Nicola Cetorelli and Pietro F. Peretto

Puzzles in the Chinese Stock Market

WP-00-13

John Fernald and John H. Rogers

The Effects of Geographic Expansion on Bank Efficiency

WP-00-14

Allen N. Berger and Robert DeYoung

Idiosyncratic Risk and Aggregate Employment Dynamics

WP-00-15

Jeffrey R. Campbell and Jonas D.M. Fisher

Post-Resolution Treatment of Depositors at Failed Banks: Implications for the Severity of Banking Crises, Systemic Risk, and Too-Big-To-Fail

WP-00-16 George G. Kaufman and Steven A. Seelig 


\section{Working Paper Series (continued)}

The Double Play: Simultaneous Speculative Attacks on Currency and Equity Markets

WP-00-17

Sujit Chakravorti and Subir Lall

Capital Requirements and Competition in the Banking Industry

WP-00-18

Peter J.G. Vlaar

Financial-Intermediation Regime and Efficiency in a Boyd-Prescott Economy

WP-00-19

Yeong-Yuh Chiang and Edward J. Green

How Do Retail Prices React to Minimum Wage Increases?

WP-00-20

James M. MacDonald and Daniel Aaronson

Financial Signal Processing: A Self Calibrating Model

WP-00-21

Robert J. Elliott, William C. Hunter and Barbara M. Jamieson

An Empirical Examination of the Price-Dividend Relation with Dividend Management

WP-00-22

Lucy F. Ackert and William C. Hunter

Savings of Young Parents

Annamaria Lusardi, Ricardo Cossa, and Erin L. Krupka

The Pitfalls in Inferring Risk from Financial Market Data

Robert R. Bliss

What Can Account for Fluctuations in the Terms of Trade?

WP-00-25

Marianne Baxter and Michael A. Kouparitsas

Data Revisions and the Identification of Monetary Policy Shocks

WP-00-26

Dean Croushore and Charles L. Evans

Recent Evidence on the Relationship Between Unemployment and Wage Growth

WP-00-27

Daniel Aaronson and Daniel Sullivan

Supplier Relationships and Small Business Use of Trade Credit

WP-00-28

Daniel Aaronson, Raphael Bostic, Paul Huck and Robert Townsend

What are the Short-Run Effects of Increasing Labor Market Flexibility?

WP-00-29

Marcelo Veracierto

Equilibrium Lending Mechanism and Aggregate Activity

WP-00-30

Cheng Wang and Ruilin Zhou

Impact of Independent Directors and the Regulatory Environment on Bank Merger Prices:

Evidence from Takeover Activity in the 1990s

Elijah Brewer III, William E. Jackson III, and Julapa A. Jagtiani

WP-00-31

Does Bank Concentration Lead to Concentration in Industrial Sectors?

WP-01-01

Nicola Cetorelli

On the Fiscal Implications of Twin Crises

WP-01-02

Craig Burnside, Martin Eichenbaum and Sergio Rebelo 


\section{Working Paper Series (continued)}

Sub-Debt Yield Spreads as Bank Risk Measures

WP-01-03

Douglas D. Evanoff and Larry D. Wall

Productivity Growth in the 1990s: Technology, Utilization, or Adjustment?

WP-01-04

Susanto Basu, John G. Fernald and Matthew D. Shapiro

Do Regulators Search for the Quiet Life? The Relationship Between Regulators and

The Regulated in Banking

Richard J. Rosen

WP-01-05

Learning-by-Doing, Scale Efficiencies, and Financial Performance at Internet-Only Banks

WP-01-06

Robert DeYoung

The Role of Real Wages, Productivity, and Fiscal Policy in Germany's

Great Depression 1928-37

WP-01-07

Jonas D. M. Fisher and Andreas Hornstein

Nominal Rigidities and the Dynamic Effects of a Shock to Monetary Policy

WP-01-08

Lawrence J. Christiano, Martin Eichenbaum and Charles L. Evans

Outsourcing Business Service and the Scope of Local Markets

WP-01-09

Yukako Ono

The Effect of Market Size Structure on Competition: The Case of Small Business Lending

WP-01-10 Allen N. Berger, Richard J. Rosen and Gregory F. Udell

Deregulation, the Internet, and the Competitive Viability of Large Banks and Community Banks WP-01-11 Robert DeYoung and William C. Hunter

Price Ceilings as Focal Points for Tacit Collusion: Evidence from Credit Cards

WP-01-12

Christopher R. Knittel and Victor Stango

Gaps and Triangles

WP-01-13

Bernardino Adão, Isabel Correia and Pedro Teles

A Real Explanation for Heterogeneous Investment Dynamics

WP-01-14

Jonas D.M. Fisher

Recovering Risk Aversion from Options

WP-01-15

Robert R. Bliss and Nikolaos Panigirtzoglou

Economic Determinants of the Nominal Treasury Yield Curve

WP-01-16

Charles L. Evans and David Marshall

Price Level Uniformity in a Random Matching Model with Perfectly Patient Traders

WP-01-17

Edward J. Green and Ruilin Zhou

Earnings Mobility in the US: A New Look at Intergenerational Inequality

WP-01-18

Bhashkar Mazumder

The Effects of Health Insurance and Self-Insurance on Retirement Behavior

WP-01-19

Eric French and John Bailey Jones 


\section{Working Paper Series (continued)}

The Effect of Part-Time Work on Wages: Evidence from the Social Security Rules

WP-01-20

Daniel Aaronson and Eric French

Antidumping Policy Under Imperfect Competition

WP-01-21

Meredith A. Crowley

Is the United States an Optimum Currency Area?

An Empirical Analysis of Regional Business Cycles

WP-01-22

Michael A. Kouparitsas

A Note on the Estimation of Linear Regression Models with Heteroskedastic

Measurement Errors

WP-01-23

Daniel G. Sullivan

The Mis-Measurement of Permanent Earnings: New Evidence from Social

Security Earnings Data

Bhashkar Mazumder

Pricing IPOs of Mutual Thrift Conversions: The Joint Effect of Regulation and Market Discipline

Elijah Brewer III, Douglas D. Evanoff and Jacky So

WP-01-25

Opportunity Cost and Prudentiality: An Analysis of Collateral Decisions in Bilateral and Multilateral Settings

Herbert L. Baer, Virginia G. France and James T. Moser

WP-01-26

Outsourcing Business Services and the Role of Central Administrative Offices

WP-02-01

Yukako Ono

Strategic Responses to Regulatory Threat in the Credit Card Market*

WP-02-02

Victor Stango

The Optimal Mix of Taxes on Money, Consumption and Income

WP-02-03

Fiorella De Fiore and Pedro Teles

Expectation Traps and Monetary Policy

Stefania Albanesi, V. V. Chari and Lawrence J. Christiano

WP-02-04

Monetary Policy in a Financial Crisis

WP-02-05

Lawrence J. Christiano, Christopher Gust and Jorge Roldos

Regulatory Incentives and Consolidation: The Case of Commercial Bank Mergers and the Community Reinvestment Act

Raphael Bostic, Hamid Mehran, Anna Paulson and Marc Saidenberg

WP-02-06

Technological Progress and the Geographic Expansion of the Banking Industry

WP-02-07

Allen N. Berger and Robert DeYoung

Choosing the Right Parents: Changes in the Intergenerational Transmission

WP-02-08

of Inequality — Between 1980 and the Early 1990s

David I. Levine and Bhashkar Mazumder 


\section{Working Paper Series (continued)}

The Immediacy Implications of Exchange Organization

WP-02-09

James T. Moser

Maternal Employment and Overweight Children

WP-02-10

Patricia M. Anderson, Kristin F. Butcher and Phillip B. Levine

The Costs and Benefits of Moral Suasion: Evidence from the Rescue of

WP-02-11

Long-Term Capital Management

Craig Furfine

On the Cyclical Behavior of Employment, Unemployment and Labor Force Participation

WP-02-12 Marcelo Veracierto

Do Safeguard Tariffs and Antidumping Duties Open or Close Technology Gaps?

WP-02-13 Meredith A. Crowley 